\title{
Novel Cephalosporins Selectively Active on Nonreplicating Mycobacterium tuberculosis
}

\author{
Ben Gold, ${ }^{\dagger}$ Robert Smith," Quyen Nguyen, ${ }^{\nabla, \#}$ Julia Roberts, ${ }^{\dagger}$ Yan Ling, ${ }^{\dagger}$ Landys Lopez Quezada, $^{\dagger}$
} Selin Somersan, ${ }^{\ddagger}$ Thulasi Warrier, ${ }^{\dagger}$ David Little, ${ }^{\dagger}$ Maneesh Pingle, ${ }^{\dagger}$ David Zhang, ${ }^{\dagger}$ Elaine Ballinger, ${ }^{\dagger}$ Matthew Zimmerman, ${ }^{\perp}$ Véronique Dartois, ${ }^{\perp}$ Paul Hanson, ${ }^{\bigcirc, \nabla}$ Lester A. Mitscher, ${ }^{\triangleleft}$,I Patrick Porubsky, ${ }^{\nabla}$ Steven Rogers, ${ }^{\#}$ Frank J. Schoenen, " Carl Nathan, ${ }^{* \dagger}$ and Jeffrey Aubé ${ }^{*, \|, \nabla, \bullet, \#}$

${ }^{\dagger}$ Department of Microbiology and Immunology and ${ }^{\ddagger}$ Department of Medicine, Weill Cornell Medical College, New York, New York 10065, United States

${ }^{\perp}$ Public Health Research Institute, New Jersey Medical School, Rutgers, the State University of New Jersey, Newark, New Jersey 07013, United States

"University of Kansas Specialized Chemistry Center, ${ }^{\nabla}$ Chemical Methodologies and Library Development Center, ${ }^{\circ}$ Department of Chemistry, and Department of Medicinal Chemistry, University of Kansas, Lawrence, Kansas 66047, United States

\#Division of Chemical Biology and Medicinal Chemistry, UNC Eshelman School of Pharmacy, University of North Carolina at Chapel Hill, Chapel Hill, North Carolina 27599, United States

Supporting Information

ABSTRACT: We report two series of novel cephalosporins that are bactericidal to Mycobacterium tuberculosis alone of the pathogens tested, which only kill $M$. tuberculosis when its replication is halted by conditions resembling those believed to pertain in the host, and whose bactericidal activity is not dependent upon or enhanced by clavulanate, a $\beta$-lactamase inhibitor. The two classes of cephalosporins bear an ester or alternatively an oxadiazole isostere at C-2 of the cephalosporin ring system, a position that is almost exclusively a carboxylic acid in clinically used agents in the class. Representatives of the series kill M. tuberculosis within macrophages without toxicity to the macrophages or other mammalian cells.

\section{INTRODUCTION}

Antibiotics that rapidly kill Mycobacterium tuberculosis in axenic culture require months to years to produce the same result in tuberculosis (TB) patients. Accordingly, TB treatment lags far behind that of other bacterial diseases in terms of treatment duration, number of antibiotics required, toxicity to the host, and cure rates. Although new drugs such as oxazolidinones (linezolid, Pfizer) ${ }^{1}$ diarylquinolines (bedaquiline, Janssen), ${ }^{2}$ and nitroimidazoles (e.g., delamanid) ${ }^{3}$ offer hope of shortening TB therapy and reducing mortality in patients whose TB is resistant to the standard regimen, there is an urgent need to discover additional anti-TB drugs.

Even when M. tuberculosis is genetically sensitive to existing drugs, a small fraction of a replicating population survives exposure to each such drug in vitro. Such bacteria are termed "persisters". They display class I phenotypic tolerance ${ }^{4}$ in that, when the drug is removed and the persisters are allowed to replicate, application of the drug at the same concentration again kills the vast majority. Mechanisms of class I persistence range from temporary nonreplication of a small subpopulation ${ }^{5}$ to heterogeneous expression of proteins that activate prodrugs and misincorporation of amino acids into proteins. $^{6-9}$ Genetically susceptible M. tuberculosis can also display class II

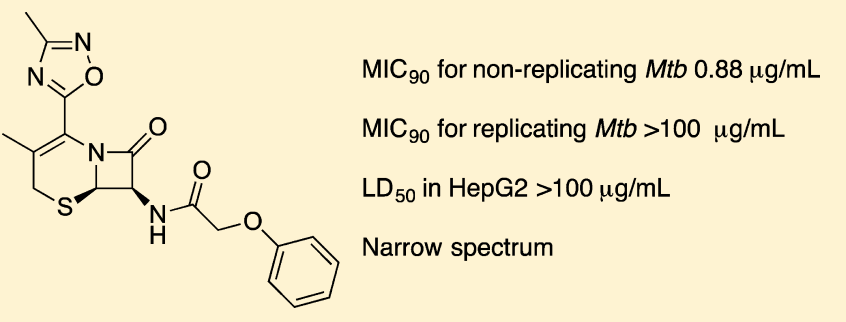

phenotypic tolerance when external stresses, such as those imposed by the host immune system, prevent most of the population from replicating. ${ }^{40-12}$ Ideally, TB should be treated with a combination of drugs such that bacteria displaying class I phenotypic tolerance to any one of them are killed by at least one of the others, and at least one of the drugs can kill nonreplicating M. tuberculosis that display class II phenotypic tolerance.

Some of the conditions in the host that can drive $M$. tuberculosis into replication arrest and class II phenotypic tolerance include residence in interferon $\gamma$ (IFN $\gamma$ )-activated macrophages that traffic the bacilli to acidified phagosomes and expose them to nitrosative and oxidative stress ${ }^{13-15}$ or release of $M$. tuberculosis into the hypoxic milieu of necrotic granulomas. ${ }^{16}$ The search for compounds active against nonreplicating $M$. tuberculosis has been pursued in a variety of in vitro nonreplicating models. ${ }^{17-30}$ We recently developed a high throughput screening platform to identify small molecules that kill class II persistent $M$. tuberculosis that are rendered nonreplicating by a combination of four host-relevant

Received: November 25, 2015

Published: May 4, 2016 


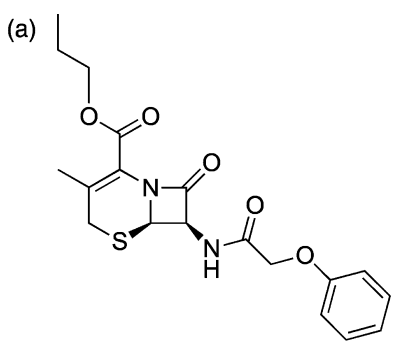

1

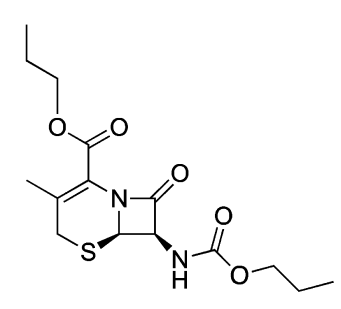

2

(c)

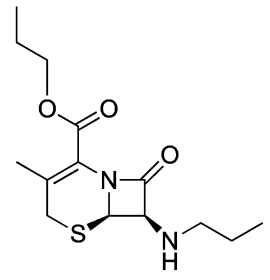

(b)

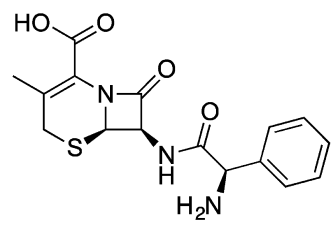

4

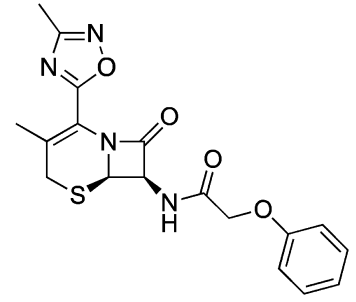

5

Figure 1. Structures of (a) cephalosporins 1-3 selectively active on nonreplicating M. tuberculosis, (b) for an inactive analogue, the clinically used antibiotic cephalexin, and (c) the C-2 oxadiazole cephalosporin 5.

Table 1. Primary Screening Actives that Target Non-Replicating M. tuberculosis

\begin{tabular}{|c|c|c|c|c|c|c|c|c|c|}
\hline compound & $\begin{array}{c}\text { NR-MIC }_{90} 3 \\
\text { days } \mathrm{OD}_{580}= \\
0.1(\mu \mathrm{g} / \mathrm{mL})\end{array}$ & $\begin{array}{c}\text { NR-MIC }{ }_{90} 6 \\
\text { days } \mathrm{OD}_{580}= \\
0.1(\mu \mathrm{g} / \mathrm{mL})\end{array}$ & $\begin{array}{l}\text { NR-MIC }_{90} 3 \\
\text { days } \mathrm{OD}_{580}= \\
0.01(\mu \mathrm{g} / \mathrm{mL})\end{array}$ & $\begin{array}{l}\text { NR-MIC }{ }_{90} 6 \\
\text { days } \mathrm{OD}_{580}= \\
0.01(\mu \mathrm{g} / \mathrm{mL})\end{array}$ & $\begin{array}{c}\mathrm{R}^{-\mathrm{MIC}_{90} 3} \\
\text { days } \mathrm{OD}_{580}= \\
0.01(\mu \mathrm{g} / \mathrm{mL})\end{array}$ & $\begin{array}{c}\text { HepG2 } \\
\text { LD50 } \\
(\mu \mathrm{g} / \mathrm{mL})\end{array}$ & $\begin{array}{l}\text { d6: \% } \\
\text { remaining } \\
\text { in PBS }\end{array}$ & $\begin{array}{l}\text { d6: } \% \\
\text { remaining } \\
\text { NR } \\
\text { medium }\end{array}$ & $\begin{array}{c}\text { d6: \% remaining } \\
\text { NR medium }+0.5 \\
\mathrm{mM} \mathrm{NaNO}_{2}\end{array}$ \\
\hline 1 & 1.76 & 1.05 & 0.90 & 0.64 & $>100$ & $>75.69$ & 80 & 100 & 100 \\
\hline 2 & 2.61 & 0.52 & 3.11 & n.t. ${ }^{a}$ & 55.44 & $>100$ & 80 & 100 & 100 \\
\hline 3 & 2.69 & 0.45 & 0.7 & n.t. ${ }^{a}$ & $>100$ & $>100$ & 100 & 100 & 40 \\
\hline cephalexin 4 & 61.35 & 70.42 & 97.93 & 73.04 & 33.99 & $>100$ & 50 & 100 & 100 \\
\hline
\end{tabular}

conditions: ${ }^{13-15,21,31-35}$ low $\mathrm{pH}$ (5.0), a flux of nitric oxide (generated from $0.5 \mathrm{mM}$ nitrite at that $\mathrm{pH}$ ), hypoxia $\left(1 \% \mathrm{O}_{2}\right)$, and low concentrations of a fatty acid ( $0.05 \%$ butyrate) as the carbon source instead of the conventional carbon sources dextrose and glycerol. ${ }^{21,36}$ Here, we report that this screening protocol has led to the discovery of the first cephalosporins, to our knowledge, that are selectively active against bacteria in a nonreplicating state. We describe an initial analysis of their structure-activity relationship.

\section{RESULTS}

Identification of Cephalosporins Active on Nonreplicating $M$. tuberculosis. A high-throughput screening campaign against replicating and nonreplicating $M$. tuberculosis was carried out using a library of compounds from an in-house screening collection assembled at the University of Kansas. This screen led to the identification of three cephalosporin esters ${ }^{37}$ (1-3, Figure 1a) whose activity was unique to nonreplicating M. tuberculosis. For comparison, cephalexin 4, a broad-spectrum antibiotic in clinical use, was also tested in the multistress nonreplicating model but found to be inactive. The three hit molecules were resynthesized to $>96 \%$ purity and displayed $\mathrm{MIC}_{90} \mathrm{~s}$ against nonreplicating $M$. tuberculosis of $1.8-2.7 \mu \mathrm{g} / \mathrm{mL}$ and $0.5-1.1 \mu \mathrm{g} / \mathrm{mL}$ during exposures lasting 3 or 6 days, respectively (Table 1 ). Initial results were obtained with a strain of $M$. tuberculosis whose dual auxotrophy for pantothenate and lysine increases its safety for laboratory personnel, ${ }^{38,39}$ and key results for select molecules were verified using virulent, wild- type $M$. tuberculosis $\mathrm{H} 37 \mathrm{Rv}$. Given the propensity of $\beta$-lactams for inoculum effects, ${ }^{40}$ we also determined the $\mathrm{MIC}_{90}$ s against nonreplicating $M$. tuberculosis using a 10 -fold lower inoculum of $\mathrm{A}_{580}$ of 0.01 . The results at 3 days $(0.7-3.1 \mu \mathrm{g} / \mathrm{mL})$ were similar to those found for the higher inoculum cultures exposed for 6 days. Activity against replicating M. tuberculosis and against human HepG2 hepatoma cells was not seen up to the highest concentration tested $(100 \mu \mathrm{g} / \mathrm{mL})$, and the best selectivity index was $\geq 250$. Thus, the activity of these compounds against M. tuberculosis was directly dependent on time of exposure and the state of nonreplication, inversely dependent on concentration of the bacteria, and selective for M. tuberculosis over human cells.

Stability in Cell-Free PBS and Nonreplicating Medium. Because some molecules are chemically unstable in the multistress model of nonreplication, ${ }^{21,35,36}$ compounds $\mathbf{1}$ and $\mathbf{2}$ were tested and found to be stable for up to 6 days in cell-free PBS and nonreplicating medium containing or omitting $\mathrm{NaNO}_{2}$ (Figure 2a and b). However, 3 was unstable in cellfree nonreplicating medium containing $\mathrm{NaNO}_{2}$ (Figure 2c; summarized in Table 1). For comparison, cephalexin was partially unstable in cell-free PBS and stable in cell-free nonreplicating medium either containing or lacking $\mathrm{NaNO}_{2}$ (Figure 2d).

Structure-Activity Relationship (SAR) Studies. These promising results prompted us to undertake an initial structure-activity relationship survey. For each new analogue, we determined the activity against $M t b$ under both non- 

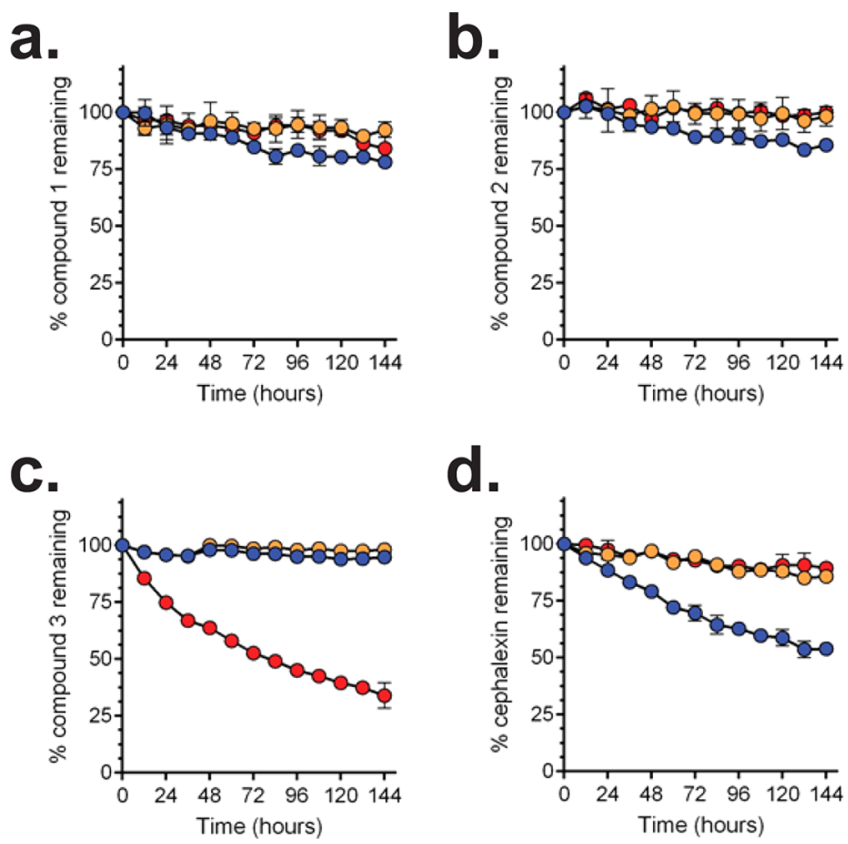

Figure 2. Cell-free stability of primary screening hits. Molecules were incubated at $37^{\circ} \mathrm{C}$ in PBS (blue) or nonreplicating medium without (orange) or with (red) $\mathrm{NaNO}_{2}$. Data are averages of replicate samples \pm standard deviation.

replicating (NR) and replicating (R) conditions. In addition, each compound was assayed for cytotoxicity against HepG2 cells. For the present discussion, analogues are presented in Tables $2-5$ according to the chemical class investigated.

To test if the ester moiety in compounds $1-3$ was essential for activity, we synthesized five free acid analogues of 1 (9) or related molecules and tested three commercially available cephalosporins bearing C-2 carboxylic acids (cephalexin, cefdinir, and cephalothin). The activity of all the cephalosporin carboxylates tested against nonreplicating $M$. tuberculosis ranged from $\sim 50$ to $>100 \mu \mathrm{g} / \mathrm{mL}$ (Table 2), signifying the importance of an ester moiety at $\mathrm{C}-2$. To determine if additional functional groups could be tolerated at this position, we prepared and tested analogues containing various amides, alcohols, and ethers at $\mathrm{C}-2$ (Table 2, compounds 5-18). All were found to be inactive. However, replacement of the ester moiety by the isosteric 1,2,4-oxadiazole in analogue 5 resulted in a compound that was close in activity to $\mathbf{1}$ (Figure 1c and Table 2). Moreover, compound $\mathbf{5}$ was stable in cell-free nonreplicating medium containing $\mathrm{NaNO}_{2}$ (Figure 3).

To determine if simply adding ester groups or an oxadiazole to C-2 of a classical cephalosporin would confer activity against nonreplicating M. tuberculosis, we made cephalexin analogues $\mathbf{4 a}-\mathbf{c}$ bearing such modifications. Testing determined that analogues $4 \mathbf{a}$ and $\mathbf{4 c}$ were poorly active against nonreplicating $M$. tuberculosis and completely inactive against replicating $M$. tuberculosis (Table 3). $n$-Propyl ester $\mathbf{4 b}$ was slightly more active with an NR-MIC ${ }_{90}$ of $15.5 \mu \mathrm{g} / \mathrm{mL}$.

Given these results, we chose to concentrate on exploring the effect of C-2 and C-7 amino substitution in two series of analogues: the esters (Table 4) and the oxadiazoles (Table 5). All compounds were synthesized as summarized in Scheme 1. Esters were generated from commercially available 7-aminodeacetoxycephalosporanic acid (7-ADCA) by amidation, followed by esterification. The oxadiazole series was prepared by installing the desired oxadiazole onto the C-2 of carboxylic acid $A^{41}$ as shown in Scheme 1 below. Compounds were typically purified by mass-directed HPLC fractionation and rendered in purities of $\geq 95 \%$ for biological evaluation.

Numerous analogues in both series of compounds were active against nonreplicating $M$. tuberculosis. The activity profiles of these molecules were responsive to these basic chemical changes, which suggested that the compounds were exerting their activity through action at a discrete cellular target. For example, a preference for longish and unbranched esters at C-2 was generally observed with ethyl, propyl, and butyl esters being preferred. Activity was sharply diminished for analogues containing propargyl groups at this position (e.g., compounds 4, 6, and 22), although benzyl esters were tolerated (compounds 14, 24, and 29). Recalling that cephalexin analogues $4 \mathrm{a}$ and $\mathbf{4 b}$ containing a side chain bearing a primary amine were poorly active, we concentrated our initial SAR on neutral C-7 amide moieties (although the single C-7 propyl amine examined, compound 3, did have significant activity). Most of the compounds examined bore a substituted 3phenylpropamide side chain or its ethereal analogue (e.g., compound 13). We also observed that moving the double bond from the $\Delta^{2,3}$ to the $\Delta^{3,4}$ had only a modest effect (cf. compounds 34 and 35 ).

Among the C-2 oxadiazoles (Table 5), similar trends were observed with a few addenda. Here, a wider range of carbamates, including a single carbothioate, were prepared and found to be active (compounds 14-17). In this series, we noted that although compounds bearing para electron-withdrawing substituents retained excellent potency, in many cases measurable levels of cellular toxicity were also observed. Particularly notable examples included some $p$ - $\mathrm{Cl}$ and 3,4dichloro analogues (compounds 5, 12, 21, and 29).

Physicochemical Properties and Metabolic Stability. Compounds $\mathbf{1}$ and $\mathbf{5}$ were chosen as representative molecules of the alkyl ester and oxadiazole classes of cephalosporins that are active against nonreplicating $M$. tuberculosis, whereas cephalexin, cefdinir, and cephalothin were chosen as representatives of cephalosporins lacking such activity. The active cephalosporins shared higher values for $\log \mathrm{P}$ and $\mathrm{p} K_{\mathrm{v}}$ whereas other properties such as $\mathrm{H}$-bond donors, $\mathrm{H}$-bond acceptors, molecular weight, heavy atom count, and rotatable bonds were similar (Table 6).

We next determined the hydrolytic stability of these compounds under strongly acidic conditions, such as would be encountered in the stomach. Both $\mathbf{1}$ and $\mathbf{5}$ were more stable at $\mathrm{pH} 2(100 \%$ remaining after $4 \mathrm{~h})$ than cephalexin $(\sim 74 \%$ remaining) (Table 7), whereas all three compounds were stable at $\mathrm{pH} 7$ and degraded in base ( $\mathrm{pH}$ 12). Compound 5 and cephalexin were soluble at 84 and $76 \mu \mathrm{M}$ at $\mathrm{pH}$ 7.4, respectively, whereas 1 was less soluble at $23 \mu \mathrm{M}$ (Table 7).

Parallel artificial membrane permeability assays (PAMPA) predicted that both $\mathbf{1}$ and $\mathbf{5}$ would be membrane permeable (Table 8). However, unlike cephalexin, both $\mathbf{1}$ and $\mathbf{5}$ were rapidly metabolized by mouse liver microsomes (Table 8 ). Compounds 1 and $\mathbf{5}$ were less susceptible to metabolism by human liver microsomes with half-lives of $\sim 80 \mathrm{~min}$ and $\mathrm{CL}_{\text {int }}$ values suggestive of slow metabolism (Table 8 ).

Next, we assessed the stability of compounds $\mathbf{1}$ and $\mathbf{5}$ in mouse plasma to determine the feasibility of testing these compounds for activity in a mouse model of tuberculosis. Both compounds $\mathbf{1}$ and $\mathbf{5}$ were completely transformed in mouse plasma in $<5 \mathrm{~min}$ (Figure 4a). In human plasma, compounds 1 and 5 had half-lives of approximately $2-3$ h (Figure $4 \mathrm{~b}$ ). 
Table 2. Survey of C-2-Substituted Cephalosporins ${ }^{b}$

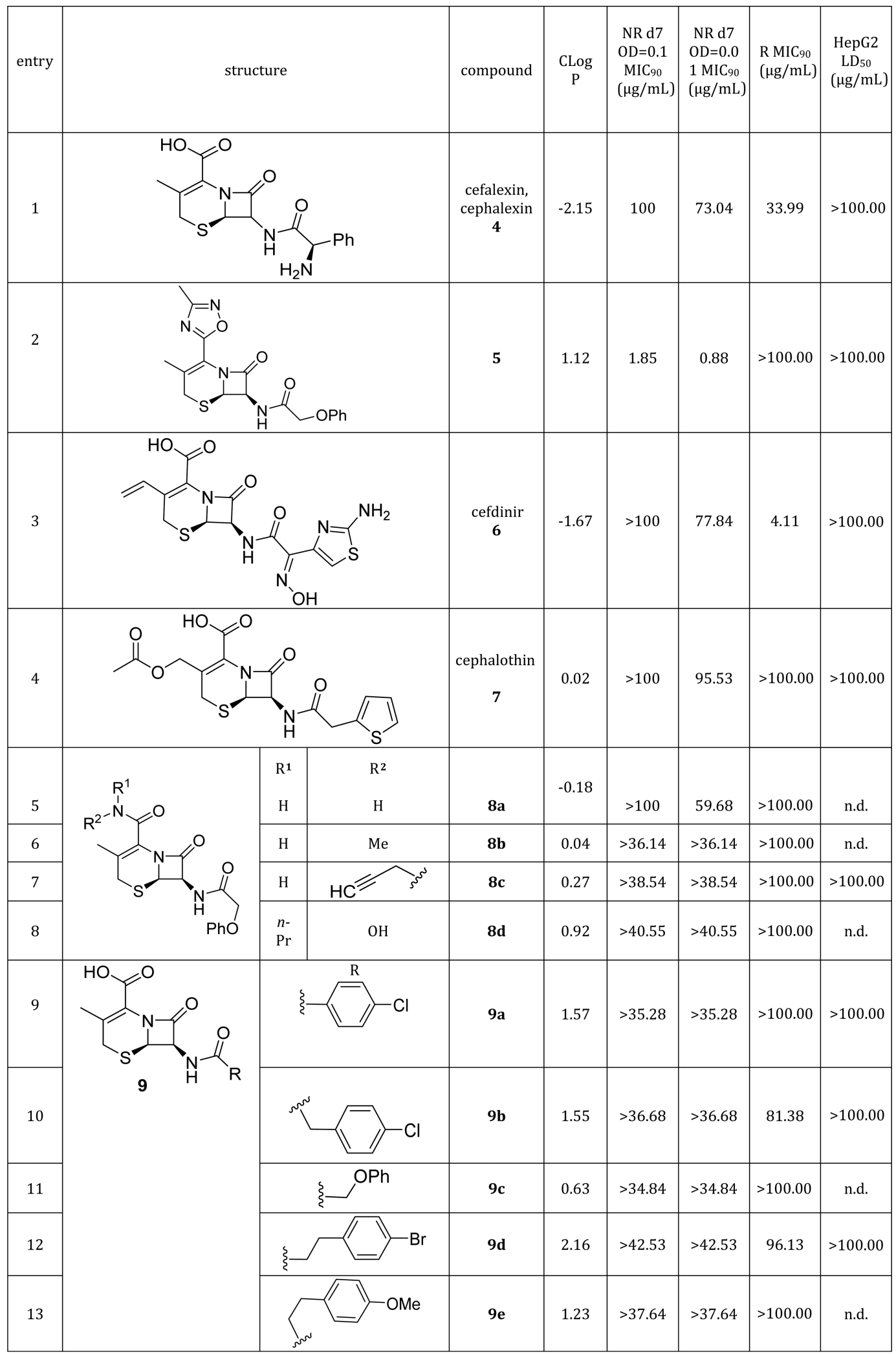


Table 2. continued

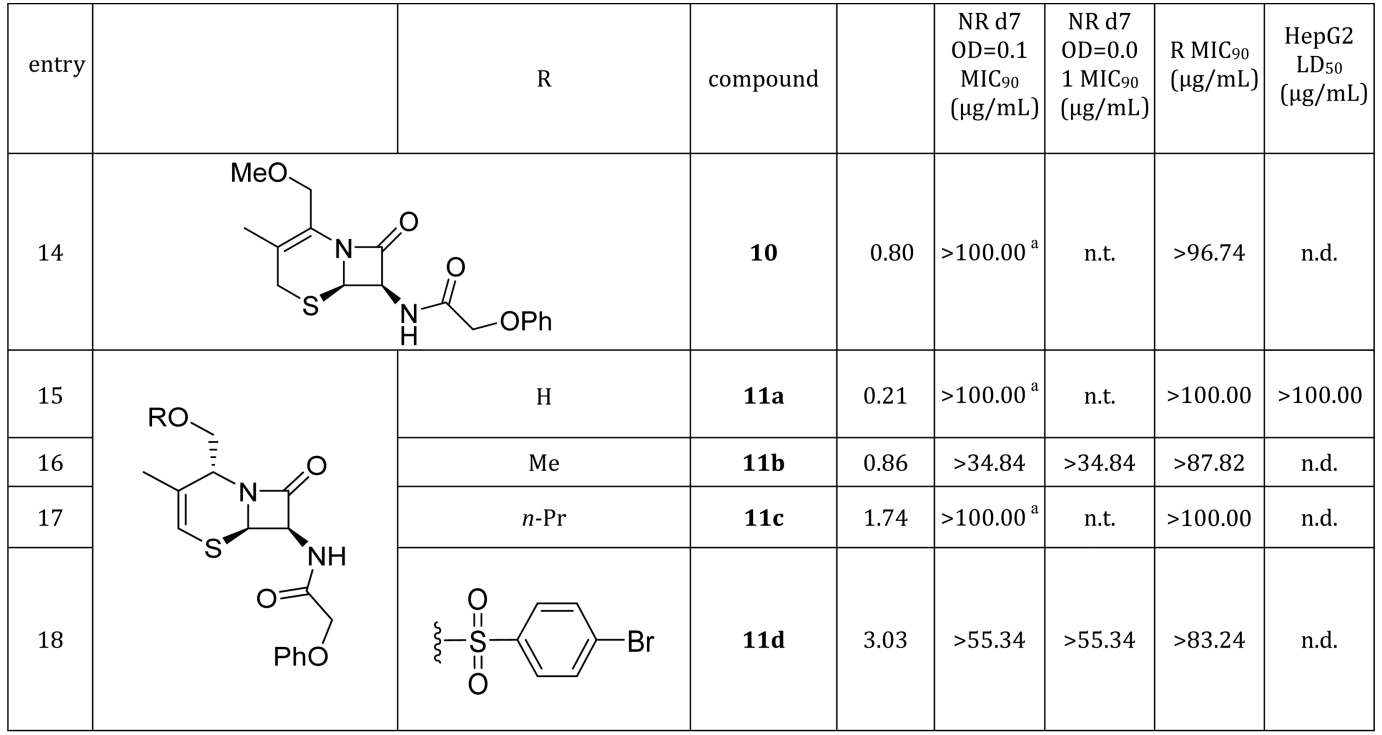

${ }^{a}$ These data were from a 3-day exposure to compound. ${ }^{b}$ n.d. $=$ not determined. n.t. $=$ not tested.

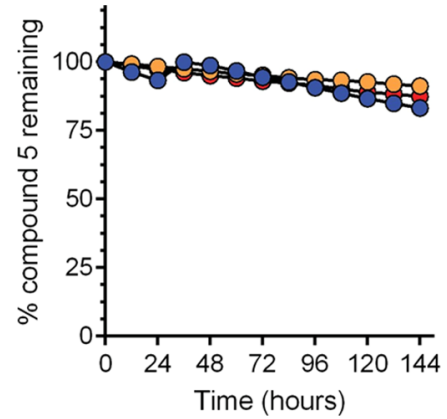

Figure 3. Cell-free stability of $\mathbf{5}$. Compound $\mathbf{5}$ was incubated at $37{ }^{\circ} \mathrm{C}$ in PBS (blue) or nonreplicating medium without (orange) or with (red) $\mathrm{NaNO}_{2}$. Data are averages of replicate samples \pm standard deviation.

Cephalexin 4 was stable in plasma from both species (Figure 4a and $b$ ).

Selective Bactericidal Action of Cephalosporins on Nonreplicating M. tuberculosis. Narrow spectrum bactericidal activity is preferred for TB drugs for two reasons. First, TB treatment is protracted, and long-term exposure to broadspectrum antibacterial agents can precipitate severe and sometimes fatal intestinal dysfunction, such as that caused by overgrowth of Clostridium difficile. Second, efficacy of a given drug against other bacterial infections can prompt its use in the community, including in people who have undiagnosed TB. Monotherapy of TB often selects for emergence of genetically resistant strains. The spread of such strains in the community would render the new drug progressively less useful for the treatment of TB. Hence, it was important to test the antimicrobial spectrum of the new cephalosporins against other bacteria. Compounds 1 and 5 had $\mathrm{MIC}_{90} \mathrm{~s}>100 \mu \mathrm{g} / \mathrm{mL}$ against replicating Pseudomonas aeruginosa, Escherichia coli, Staphylococcus aureus, Mycobacterium smegmatis, and Mycobacterium bovis BCG as well as against the fungus Candida albicans (Figure S1).

To determine the extent of bacterial kill, we exposed nonreplicating wild-type $M$. tuberculosis at an $\mathrm{OD}_{580}$ of 0.01 (low inoculum) to 1 and 5 for 7 days (Figure 5). At $\sim 0.7-0.8$ $\mu \mathrm{g} / \mathrm{mL}$, both compounds reduced colony-forming units (CFUs) by $2 \log _{10}$. Compounds 1 and 5 , at 3 and $10 \mu \mathrm{g} /$ $\mathrm{mL}$, respectively, reduced $\mathrm{CFU}$ to the extent that there were no recoverable colonies when $10 \mu \mathrm{L}$ of undiluted sample was plated $\left(\geq 3.4 \log _{10}\right.$ kill). Thus, no class I phenotypic tolerance was observed. Bactericidal activity of $\mathbf{1}$ was not enhanced by the addition of a $\beta$-lactamase inhibitor, clavulanate, and addition of clavulanate did not lead to activity of 3,2 , or 1 against replicating $M$. tuberculosis (data not shown). In contrast, clavulanate enhanced the replicating $\mathrm{MIC}_{90}$ of Meropenem 4fold.

Representative cephalosporins (compounds 5, 12e, 12i, 18d, 19d, 21b, 22c, and 23) from the preliminary SAR campaign (Tables 2-5) were tested for activity against nonreplicating wild-type M. tuberculosis. Analogues derived from compounds 1 and $\mathbf{5}$ were bactericidal in this assay (Figure S2).

Reactive Nitrogen Species Enhance Bactericidal Activity of 1 and 5 against Nonreplicating $M$. tuberculosis. The activity of $\mathbf{1}$ against nonreplicating M. tuberculosis increased in relation to the concentration of $\mathrm{NaNO}_{2}$ (Figure $6 \mathrm{a})$, whereas that of rifampicin did not at $\leq 0.5 \mathrm{mM} \mathrm{NaNO}_{2}$ (Figure 6b). At $1 \mathrm{mM} \mathrm{NaNO}_{2}$, double the concentration used in the nonreplicating screening, we observed nitrite-dependent killing with rifampicin as well. We then tested both $\mathbf{1}$ and $\mathbf{5}$ for nitrite-dependence by coupling the outgrowth to a CFUsurrogate assay (charcoal agar resazurin assay; CARA) ${ }^{42}$ that determines the approximate concentration of compound leading to $\geq 2-3 \log _{10}$ CFU reduction as reflected by the ability of survivors to convert resazurin to a fluorescent product. Both 1 and $\mathbf{5}$ decreased fluorescence in a dose-dependent manner that was strongly enhanced by the addition of $\mathrm{NaNO}_{2}$ (Figure $6 \mathrm{c}$ and $\mathrm{d}$ ). As observed for many of the $\beta$-lactams in this study, the activities of both $\mathbf{1}$ and $\mathbf{5}$ were more potent at a 10 -fold lower inoculum of 0.01 and 7-day exposure (Figure 6d). Both compounds displayed nitrite-independent activity at the lower inoculum (Figure $6 \mathrm{c}$ and Figure $6 \mathrm{~d}$ ). Thus, nitrite contributed to a 32- to 64-fold enhancement of 1's activity, but activity was not strictly dependent on an exogenous source of nitrite (Figure 6d). 
Table 3. C-2 Ester and Oxadiazole Analogues of Cephalexin

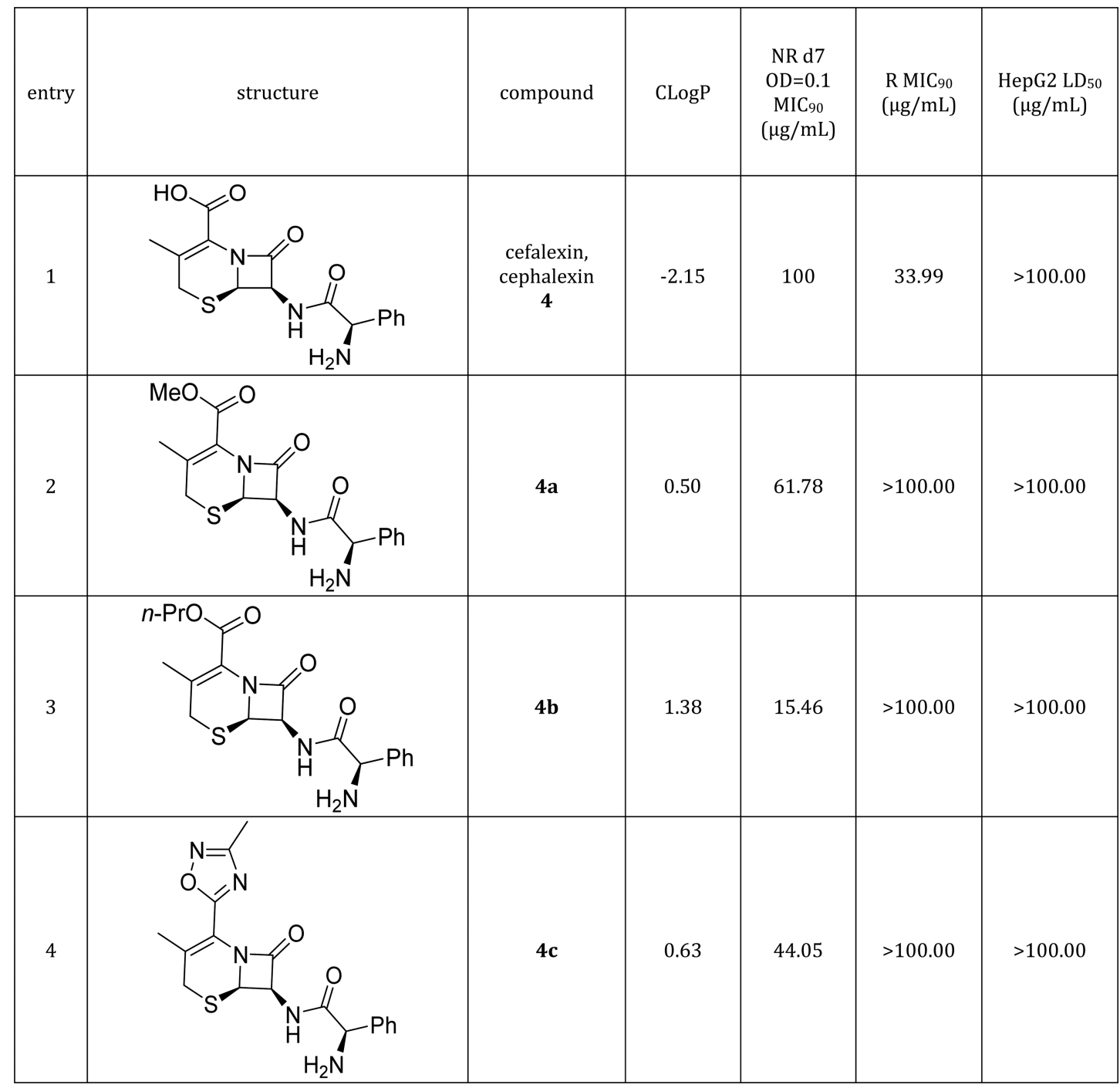

Nonreplicating-Active Cephalosporins Kill M. tuberculosis in Macrophages. Wild-type M. tuberculosis is typically growth-arrested, or replicates slowly, in activated macrophages, due in part to phagosomal acidification and macrophage production of reactive nitrogen species (RNS). ${ }^{13,14}$ The multistress nonreplicating assay conditions were designed in part to mimic this phagosomal microenvironment. ${ }^{2,35} \mathrm{We}$ hypothesized that cephalosporins active in the nonreplicating model might be bactericidal against intracellular M. tuberculosis. To test this, we stimulated mouse bone marrow-derived macrophages with IFN $\gamma$, or left them unstimulated, infected them with wild-type $M$. tuberculosis, and treated them with $\mathbf{1}, \mathbf{5}$, or diluent alone. We observed approximately $1-2 \log _{10} \mathrm{CFU}$ reduction of intracellular $M$. tuberculosis in activated macrophages treated with $\mathbf{1}$ or $\mathbf{5}$ with no apparent toxicity to the macrophages. Compound 5's bactericidal activity against intracellular M. tuberculosis was strictly IFN $\gamma$ dependent (Figure $7 \mathrm{a}$ and $\mathrm{b})$.

\section{DISCUSSION}

To our knowledge, this is the first report of $\beta$-lactams that only kill a given bacterium when it is nonreplicating, and the first report of $\beta$-lactams with activity against any one bacterial species that lacks broad-spectrum antibacterial activity. Early studies by Tuomanen et al. demonstrated that although many $\beta$-lactams lack activity against nongrowing cells, a minority killed starved, nonreplicating Escherichia coli and Streptococcus pneumonia. $^{43,44}$ Similar findings were recently observed in $M$. tuberculosis, as the combination of Meropenem and the $\beta$ lactamase inhibitor clavulanate killed both replicating and hypoxic, nonreplicating M. tuberculosis. ${ }^{45}$ Meropenem-clavulanate lacked activity against nonreplicating $M$. tuberculosis in the conditions studied here. In addition to hypoxia, our conditions included a low $\mathrm{pH}$, a flux of reactive nitrogen species, and a fatty acid carbon source. Faropenem was also reported to kill both replicating and nongrowing $M$. tuberculosis. ${ }^{46}$ Like Meropenem, faropenem was inactive in our multistress model of nonreplication. The novel cephalosporins described here did not acquire activity against replicating $M$. tuberculosis when we included clavulanate in the assays.

Structurally, the two main classes of compounds explored herein differ from clinically used cephalosporins by the lack of a carboxylic acid moiety at C-2 (a notable exception being the prodrug cefuroxime axetil), and indeed, we showed that carboxylic acid 9 is inactive against nonreplicating Mtb. Early in this project, we considered whether the screening hit propyl ester was functioning as a prodrug, but the successful 
Table 4. SAR of C-2 Cephalosporin Esters ${ }^{b}$

\begin{tabular}{|c|c|c|c|c|c|c|c|c|}
\hline entry & $\mathrm{R}^{1}$ & $\mathrm{R}^{2}$ & compound & CLogP & $\begin{array}{c}\mathrm{NR} \mathrm{d7} \\
\mathrm{OD}=0.1 \\
\mathrm{MIC}_{90} \\
(\mu \mathrm{g} / \mathrm{mL})\end{array}$ & $\begin{array}{c}\text { NR d7 } \\
\text { OD }=0.01 \\
\text { MIC } 90 \\
(\mu \mathrm{g} / \mathrm{mL})\end{array}$ & $\begin{array}{l}\mathrm{R} \mathrm{MIC}_{90} \\
(\mu \mathrm{g} / \mathrm{mL})\end{array}$ & $\begin{array}{l}\text { HepG2 } \\
\text { LD }_{50} \\
(\mu \mathrm{g} / \mathrm{mL})\end{array}$ \\
\hline \multicolumn{9}{|c|}{ 12 } \\
\hline 1 & $\mathrm{H}$ & $\mathrm{Me}$ & $12 a$ & 1.77 & 1.27 & 1.04 & $>100.00$ & $>100.00$ \\
\hline 2 & $\mathrm{H}$ & Et & $12 b$ & 2.12 & 1.15 & 0.47 & $>100.00$ & $>100.00$ \\
\hline 3 & $\mathrm{H}$ & $n-\operatorname{Pr}$ & $12 c$ & 2.65 & 1.24 & 0.6 & 53.64 & $>100.00$ \\
\hline 4 & $\mathrm{H}$ & & 12d & 1.99 & $19.97 \mathrm{a}$ & $1.11^{\mathrm{a}}$ & $>100.00$ & $>100.00$ \\
\hline 5 & $\mathrm{H}$ & $n-\mathrm{Bu}$ & $12 \mathrm{e}$ & 3.09 & $<0.24$ & 0.21 & $>100.00$ & $>100.00$ \\
\hline 6 & $p-\mathrm{Cl}$ & & $12 f$ & 2.60 & $7.85^{\mathrm{a}}$ & $0.56^{\mathrm{a}}$ & $>100.00$ & $>100.00$ \\
\hline 7 & $p-\mathrm{Cl}$ & $n-\mathrm{Bu}$ & $12 \mathrm{~g}$ & 3.69 & 1.24 & 0.72 & $>100.00$ & $>100.00$ \\
\hline 8 & $p$-OMe & $\mathrm{Me}$ & $12 \mathrm{~h}$ & 1.61 & 3.28 & $0.39^{a}$ & 59.82 & $>100.00$ \\
\hline 9 & $p$-OMe & Et & $12 \mathrm{i}$ & 1.97 & 0.51 & 0.4 & 21.37 & $>100.00$ \\
\hline 10 & $p$-OMe & $n-\operatorname{Pr}$ & $12 j$ & 2.49 & $<0.20$ & $<0.20$ & $>100.00$ & $>100.00$ \\
\hline 11 & $p$-OMe & & $12 k$ & 2.91 & 2.95 & 1.57 & $>100.00$ & n.d. \\
\hline 12 & $p$-OMe & $n-\mathrm{Bu}$ & 121 & 2.93 & 0.26 & 0.24 & $>100.00$ & $>100.00$ \\
\hline 13 & $p$-OMe & & $12 n$ & 2.96 & 0.96 & 0.84 & 44.33 & n.d. \\
\hline 14 & $p$-OMe & Benzyl & 120 & 3.33 & 0.42 & 0.39 & $>100.00$ & $>100.00$ \\
\hline
\end{tabular}




\section{Table 4. continued}

\begin{tabular}{|c|c|c|c|c|c|c|c|c|}
\hline entry & $\mathrm{R}^{1}$ & $\mathrm{R}^{2}$ & compound & CLogP & $\begin{array}{c}\mathrm{NR} d 7 \\
\mathrm{OD}=0.1 \\
\mathrm{MIC} \mathrm{C}_{90} \\
(\mu \mathrm{g} / \mathrm{mL})\end{array}$ & $\begin{array}{c}\text { NR d7 } \\
\text { OD }=0.01 \\
\text { MIC } 90 \\
(\mu \mathrm{g} / \mathrm{mL})\end{array}$ & $\begin{array}{l}\mathrm{R} \mathrm{MIC}_{90} \\
(\mu \mathrm{g} / \mathrm{mL})\end{array}$ & $\begin{array}{c}\text { HepG2 } \\
\text { LD } \\
(\mu \mathrm{g} / \mathrm{mL})\end{array}$ \\
\hline \multicolumn{9}{|c|}{$\underbrace{\mathrm{R}^{2} \mathrm{O}}_{13}$} \\
\hline 15 & $\mathrm{H}$ & $\mathrm{Me}$ & $13 a$ & 1.00 & 2.93 & 2.07 & $>100.00$ & $>100.00$ \\
\hline 16 & $\mathrm{H}$ & Et & $13 b$ & 1.36 & 1.71 & 0.66 & 57.85 & $>100.00$ \\
\hline 17 & $\mathrm{H}$ & $n-\operatorname{Pr}$ & 1 & 1.88 & 1.05 & 0.64 & $>100.00$ & $>100.00$ \\
\hline 18 & $\mathrm{H}$ & $\mathrm{H}_{2} \mathrm{~N}^{-}$ & $13 c$ & 0.26 & 8.12 & 5.60 & $>100.00$ & n.d. \\
\hline 19 & $p$-Cl & $\mathrm{Me}$ & 13d & 1.61 & 1.25 & 0.95 & $>100.00$ & $>100.00$ \\
\hline 20 & $p$-Cl & Et & $13 e$ & 1.97 & 2.38 & 1.07 & $>100.00$ & 41.02 \\
\hline 21 & $p$-Cl & $n-\operatorname{Pr}$ & $13 \mathrm{f}$ & 2.49 & 1.34 & 0.66 & $>100.00$ & 49.22 \\
\hline 22 & $p$-Cl & & $13 g$ & 1.84 & 3.95 & 1.53 & $>100.00$ & 63.41 \\
\hline 23 & $p$-Cl & $n$-Bu & $13 \mathrm{~h}$ & 2.93 & 1.01 & 0.43 & $>100.00$ & $>100.00$ \\
\hline 24 & $p$-Cl & Benzyl & $13 i$ & 3.33 & 8.07 & 0.87 & $>100.00$ & $>100.00$ \\
\hline 25 & $p$-OMe & $\mathrm{Me}$ & $13 j$ & 0.85 & 4.28 & 2.01 & $>100.00$ & $>100.00$ \\
\hline 26 & $p$-OMe & Et & $13 k$ & 1.20 & 0.89 & 0.53 & 47.10 & $>100.00$ \\
\hline 27 & $p$-OMe & $n-\operatorname{Pr}$ & 131 & 1.73 & 0.81 & 0.39 & $>100.00$ & $>100.00$ \\
\hline 28 & $p$-OMe & $n$-Bu & $13 m$ & 2.17 & 1.12 & 0.71 & $>100.00$ & $>100.00$ \\
\hline
\end{tabular}


Table 4. continued

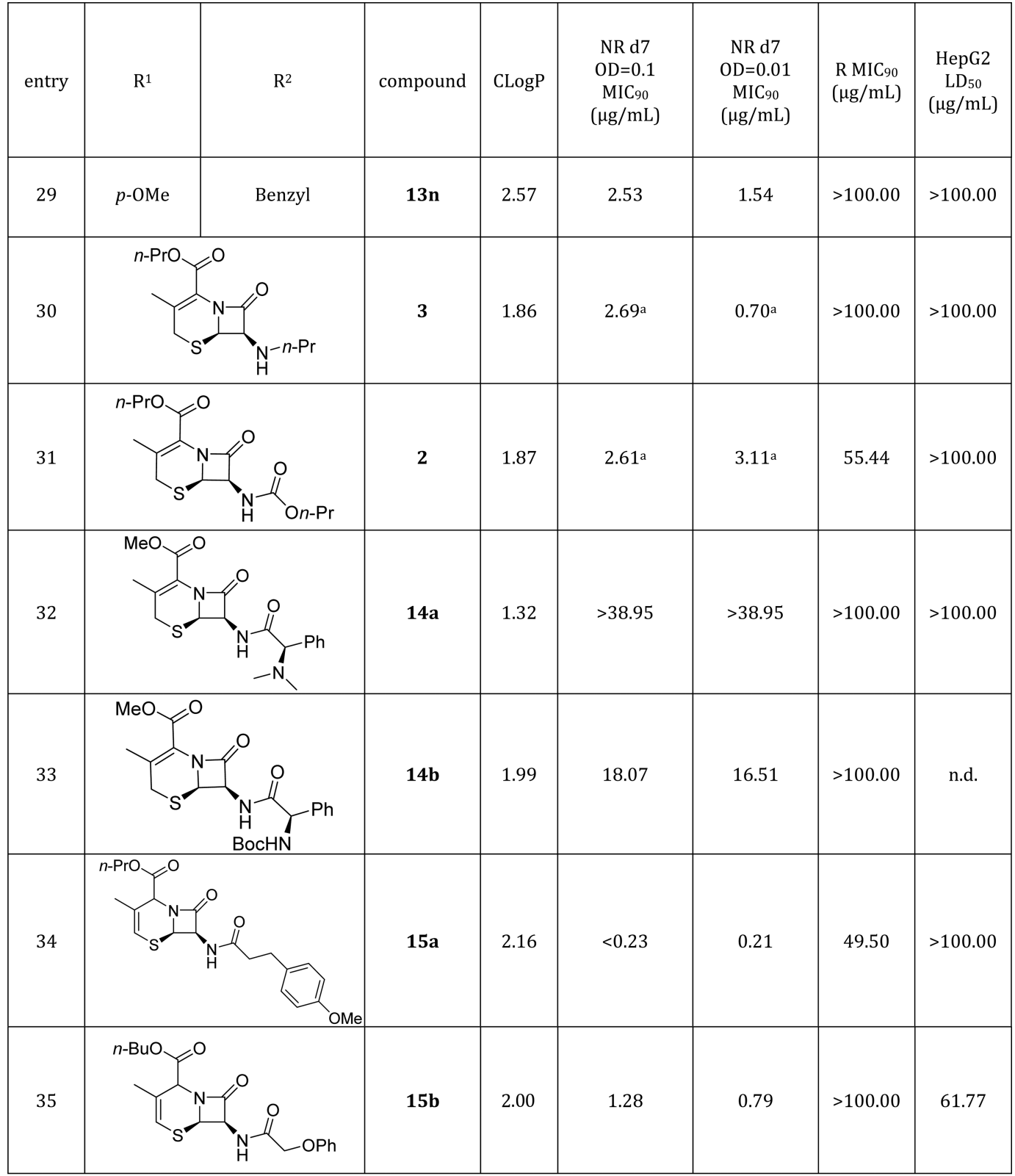

${ }^{a}$ These data were from a 3-day exposure to compound. ${ }^{b}$ n.d. $=$ not determined.

replacement of this moiety with the corresponding oxadiazole renders this possibility unlikely. A hydrophobic moiety at this position is tolerated, as seen with the $n$-propyl ester and oxadiazole, and possibly preferred, given the fact that the C-2 hydroxymethyl analogue $\mathbf{1 0}$ is inactive. Polarity at this position also plays a role given the inactivity of the amide analogous to the active esters. In the preliminary SAR pursued to date, we have also ascertained that biological activity is affected by the amide moiety attached to the central cephalosporin nucleus with chains ending in electron-poor aromatic rings being preferred and a moderate dependence of activity on the length of the chain leading to this point. The role of the $\beta$-lactam itself is currently ambiguous; although we know that hydrolytic cleavage of this ring results in an inactive compound, it is not clear whether this is because the $\beta$-lactam is essential per se, i.e., in analogy to the generally accepted mechanism of most $\beta$ lactams, which involve covalent binding of this group to the target protein, or because of a structural alignment resulting from the cephalosporin ring system.

A question of pressing interest is the molecular target that renders these cephalosporins profoundly active against $M$. tuberculosis in a nonreplicating state. Experiments to address this are underway by a variety of approaches but have not yet yielded an answer, although we note that our observation of structure-activity relationships is consistent with action through one or more specific targets. The canonical role of $\beta$-lactams in killing replicating bacteria has been widely accepted as the arrest of peptidoglycan biosynthesis. Disruption of the balance between new peptidoglycan synthesis and peptidoglycan cleavage by hydrolases leads to cellular lysis ${ }^{47,48}$ due to a futile cycle in the synthetic pathway. ${ }^{49}$ The sensitivity of hypoxic M. tuberculosis to Meropenem and clavulanate, albeit significantly less than the sensitivity of replicating $M$. tuberculosis, suggests that $M$. tuberculosis may require peptidoglycan 
Scheme 1. Synthetic Route for the Preparation of Ester and Oxadiazole Analogues

(a)

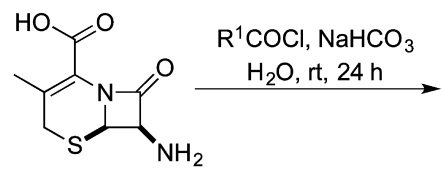

7-ADCA

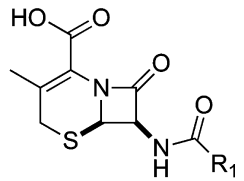

A

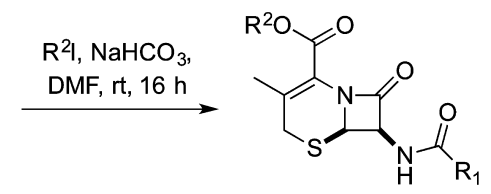

Ester series 1

(b)

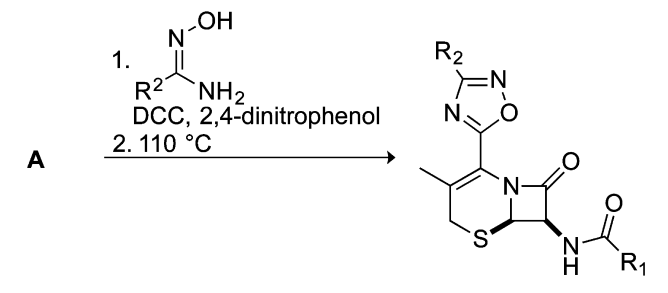

Oxadiazole series 2

biosynthesis to survive the hypoxic state. ${ }^{45}$ In addition to classical D,D-transpeptidases that catalyze the formation of $4^{\prime}$ $\rightarrow 3^{\prime}$ peptidoglycan cross-links, $M$. tuberculosis may use at least five L,D-transpeptidases ( $\mathrm{Ldt}_{\mathrm{MT} 1}-\mathrm{Ldt}_{\mathrm{MT} 5}$; LDTs) for peptidoglycan $3^{\prime} \rightarrow 3^{\prime}$ cross-linking. The $3^{\prime} \rightarrow 3^{\prime}$ cross-links account for $\sim 80 \%$ of peptidoglycan extracted from M. tuberculosis in stationary phase, a form of nonreplication. ${ }^{50}$ One of the nonclassical L,D-transpeptidases, $\mathrm{Ldt}_{\mathrm{MT} 2}$, plays a role in $M$. tuberculosis virulence in a mouse model of infection. ${ }^{51}$ Meropenem and other carbapenems bind recombinant $\mathrm{Ldt}_{\mathrm{MT1} 12,4,5}{ }^{52}$ However, there are additional covalent targets of $\beta$-lactams, such as signal peptidases and proteases. ${ }^{53-55}$ Thus, we anticipate that $\beta$-lactams that specifically target nonreplicating populations may have either single or multiple canonical or noncanonical targets.

Two of the cephalosporins with activity against nonreplicating $M$. tuberculosis were stable in PBS and in nonreplicating medium, whether or not the medium contained $\mathrm{NaNO}_{2}$. An equipotent compound, 3, was unstable. Thus, 3 may have entered the bacilli or otherwise exerted its bactericidal effect before its structure was transformed in the extracellular medium.

In animal and human tuberculosis, $M$. tuberculosis often resides in macrophages, ${ }^{56}$ and the ability to kill intracellular bacilli is an important feature of antimycobacterial compounds. Two of the nonreplicating active cephalosporins, compounds 1 and 5, killed intracellular $M$. tuberculosis but with differential dependences on immune activation. Immune activation of $M$. tuberculosis-infected macrophages leads to profound changes of the phagosomal microenvironment that are anticipated to lead to growth arrest. These changes include phagosomal acidification to approximately $\mathrm{pH} 4.5$ and induction of iNOS, which produces nitric oxide. ${ }^{14,15} M$. tuberculosis exhibits variable behavior in mouse bone marrow-derived macrophages, ranging from subexponential replication in nonactivated macrophages to slower replication, no net change in CFU, or a modest decline in CFU in activated macrophages. An inhibitor of dihydrolipoamide acyltransferase (DlaT) selectively kills $M$. tuberculosis and $M$. bovis BCG in vitro when they are nonreplicating, and this compound is effective against $M$. bovis BCG in activated macrophages. ${ }^{17}$ Likewise, compound $\mathbf{5}$ killed intracellular $M$. tuberculosis when the macrophages were immune stimulated, consistent with our hypothesis that compound $\mathbf{5}$ exerts activity in an acidic, nitrosative phagosome. However, compound 1 killed intracellular $M$. tuberculosis both in the absence and presence of IFN $\gamma$ activation and thus may possess some activity against replicating $M$. tuberculosis at the concentrations tested.

\section{SUMMARY}

The potential ability of $\beta$-lactams to treat $\mathrm{TB}$ has been suggested for many years but has only recently gained substantial notice with the report of promising results using Meropenem in human trials. ${ }^{45,46}$ It would be of considerable interest to test the role of $\beta$-lactams that target nonreplicating $M$. tuberculosis in TB therapy in combination with agents active against replicating $M$. tuberculosis. Cephalosporins with activity against nonreplicating $M$. tuberculosis identified in this study, $\mathbf{5}$ and 1 , were nontoxic, stable in cell-free medium, stable at $\mathrm{pH} 2$ and 7 , soluble at $\mathrm{pH} 7.4$, predicted to be membrane-permeable, active in macrophages, and inactive against the other bacterial and yeast species tested. Compounds $\mathbf{1}$ and $\mathbf{5}$ were relatively stable when incubated with human liver microsomes. Although compounds $\mathbf{1}$ and $\mathbf{5}$ were highly labile in mouse plasma, they were more stable in human plasma with half-lives of 2-3 h. Some analogues of compound 5 were active in the $\mathrm{ng} / \mathrm{mL}$ range. We are continuing to study the SAR of $\mathbf{5}$ while seeking its targets.

\section{EXPERIMENTAL SECTION}

General Procedure for Synthesis of Esters: Propyl (6R,7R)-3Methyl-8-oxo-7-(2-phenoxyacetamido)-5-thia-1-azabicyclo[4.2.0]oct-2-ene-2-carboxylate (1). ${ }^{37}$ To $(6 R, 7 R)$-3-methyl-8-oxo7-(2-phenoxyacetamido)-5-thia-1-azabicyclo[4.2.0] oct-2-ene-2-carboxylic acid $(197.0 \mathrm{mg}, 0.57 \mathrm{mmol})$ was added sodium bicarbonate (48 $\mathrm{mg}, 0.57 \mathrm{mmol})$ and a minimal amount of water $(6.0 \mathrm{~mL})$ to dissolve the starting material. The mixture was stirred at $\mathrm{rt}$ for $30 \mathrm{~min}$ until all solids were dissolved and then frozen and lyophilized. DMF $(10.0 \mathrm{~mL})$ was slowly added followed by 1-iodopropane $(0.55 \mathrm{~mL}, 5.7 \mathrm{mmol})$. The reaction was stirred at $\mathrm{rt}$ for $16 \mathrm{~h}$, then quenched with water, and extracted twice with $\mathrm{Et}_{2} \mathrm{O}$. The $\mathrm{Et}_{2} \mathrm{O}$ layers were combined and then washed 3 times with water and once with brine solution. The organic layer was dried $\left(\mathrm{Na}_{2} \mathrm{SO}_{4}\right)$, filtered, and concentrated. The residue was purified via MPLC (silica, 30\% EtOAc/hexanes $\rightarrow 70 \%$ EtOAc/ hexanes) to afford the title compound (130.0 mg, 59\% yield). $[\alpha]_{\mathrm{D}}^{25}$ +71.2 (c 1.45, $\mathrm{CH}_{2} \mathrm{Cl}_{2}$ ); IR (film) $\nu_{\max } 1780,1721,1687,1524,1494$, $1228,755 \mathrm{~cm}^{-1}$; ${ }^{1} \mathrm{H}$ NMR $\left(500 \mathrm{MHz}, \mathrm{CDCl}_{3}\right) \delta 7.34(\mathrm{~m}, 2 \mathrm{H}), 7.30(\mathrm{~s}$, $1 \mathrm{H}), 7.05(\mathrm{tt}, J=7.7,1.0 \mathrm{~Hz}, 1 \mathrm{H}), 6.94(\mathrm{~m}, 2 \mathrm{H}), 5.88(\mathrm{dd}, J=9.2,4.7$ $\mathrm{Hz}, 1 \mathrm{H}), 5.04(\mathrm{~d}, J=4.8 \mathrm{~Hz}, 1 \mathrm{H}), 4.58(\mathrm{~s}, 2 \mathrm{H}), 4.24(\mathrm{~m}, 2 \mathrm{H}), 3.53$ $(\mathrm{dd}, J=18.3,1.0 \mathrm{~Hz}, 1 \mathrm{H}), 3.22(\mathrm{~d}, J=18.3 \mathrm{~Hz}, 1 \mathrm{H}), 2.15(\mathrm{~s}, 3 \mathrm{H}), 1.75$ (h, $J=7.4 \mathrm{~Hz}, 2 \mathrm{H}), 0.99(\mathrm{t}, J=7.4 \mathrm{~Hz}, 3 \mathrm{H}) ;{ }^{13} \mathrm{C}$ NMR $(126 \mathrm{MHz}$, $\left.\mathrm{CDCl}_{3}\right) \delta 168.80,164.03,162.35,157.03,130.88,129.96,129.80$, $123.01,122.52,115.05,114.90,67.51,67.25,58.44,56.94,30.27$, 22.03, 20.18, 10.61; HRMS (ESI-TOF) calcd for $\mathrm{C}_{19} \mathrm{H}_{22} \mathrm{~N}_{2} \mathrm{O}_{5} \mathrm{SNH}_{4}{ }^{+}$ $\left[\mathrm{M}+\mathrm{NH}_{4}\right]^{+}$408.1588, found 408.1605.

General Procedure for Synthesis of Oxadiazoles: $N-((6 R, 7 R)$ 3-Methyl-2-(3-methyl-1,2,4-oxadiazol-5-yl)-8-oxo-5-thia-1azabicyclo[4.2.0]oct-2-en-7-yl)-2-phenoxyacetamide (5). To a solution of 2,4-dinitrophenol $(1.03 \mathrm{~g}, 5.61 \mathrm{mmol})$ in $\mathrm{CH}_{2} \mathrm{Cl}_{2}(10 \mathrm{~mL})$ was sequentially added $(6 R, 7 R)$-3-methyl-8-oxo-7-(2-phenoxyacetamido)-5-thia-1-azabicyclo[4.2.0] oct-2-ene-2-carboxylic acid (1.92 g, 5.5 $\mathrm{mmol})$ in a minimal amount of 1,4-dioxane $(8 \mathrm{~mL})$ and DCC $(1.15 \mathrm{~g}$, $5.6 \mathrm{mmol})$ in $8 \mathrm{~mL}$ of $\mathrm{CH}_{2} \mathrm{Cl}_{2}$. The mixture was stirred at $\mathrm{rt}$ for 30 $\mathrm{min}$, after which the mixture was filtered through a plug of cotton to 
Table 5. SAR of C-2 Cephalosporin Oxadiazoles ${ }^{b}$

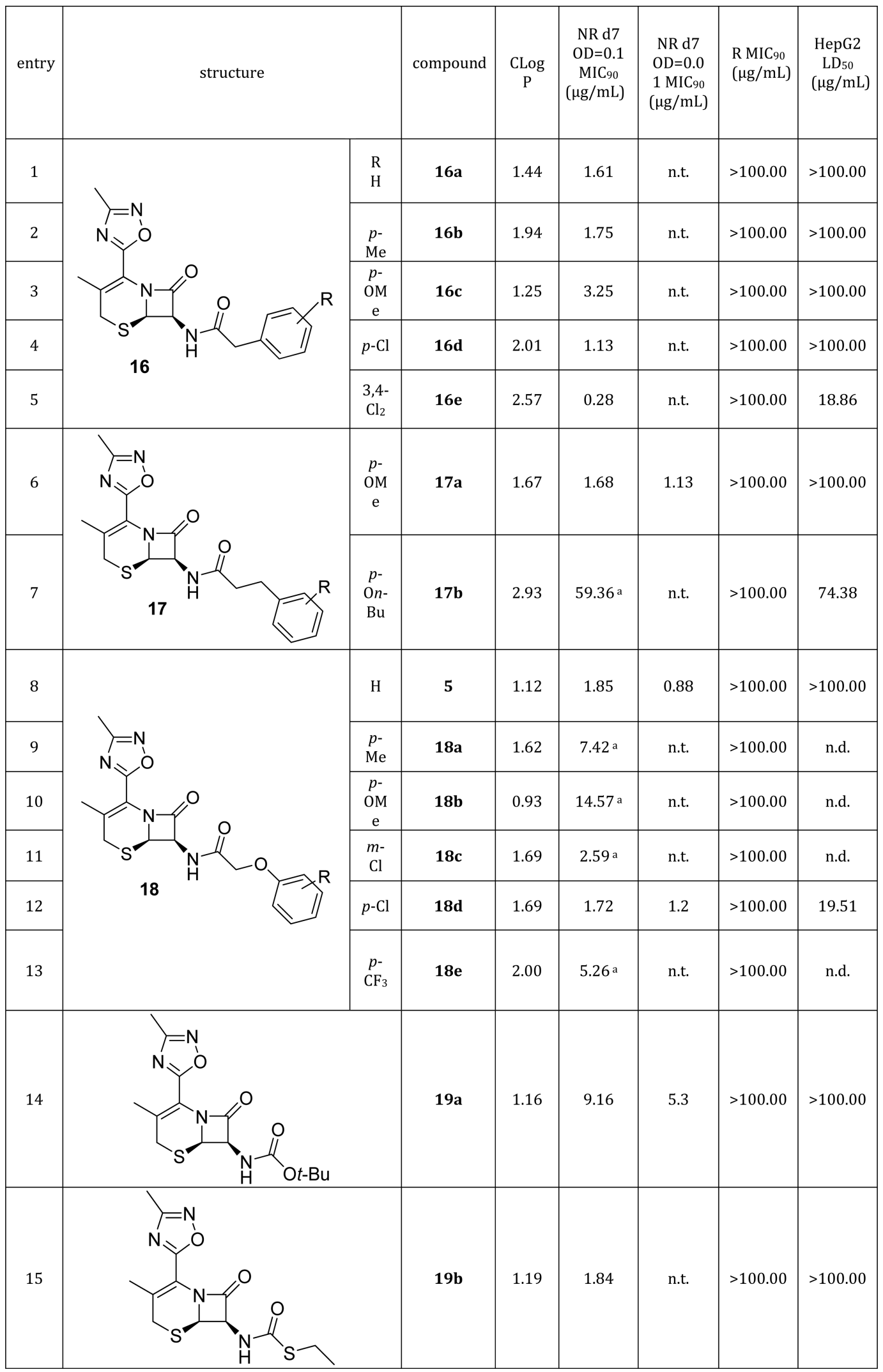


Table 5. continued

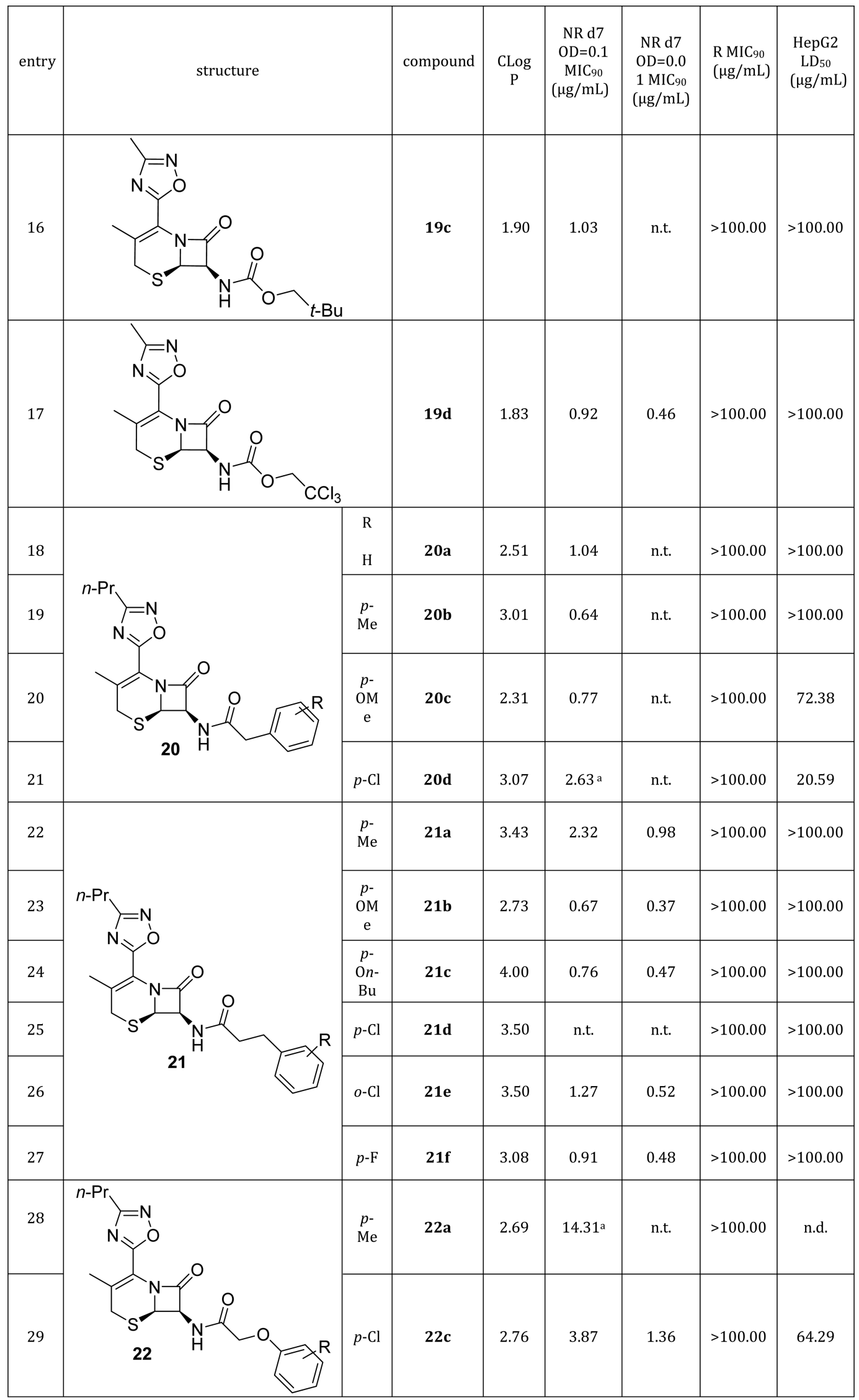


Table 5. continued

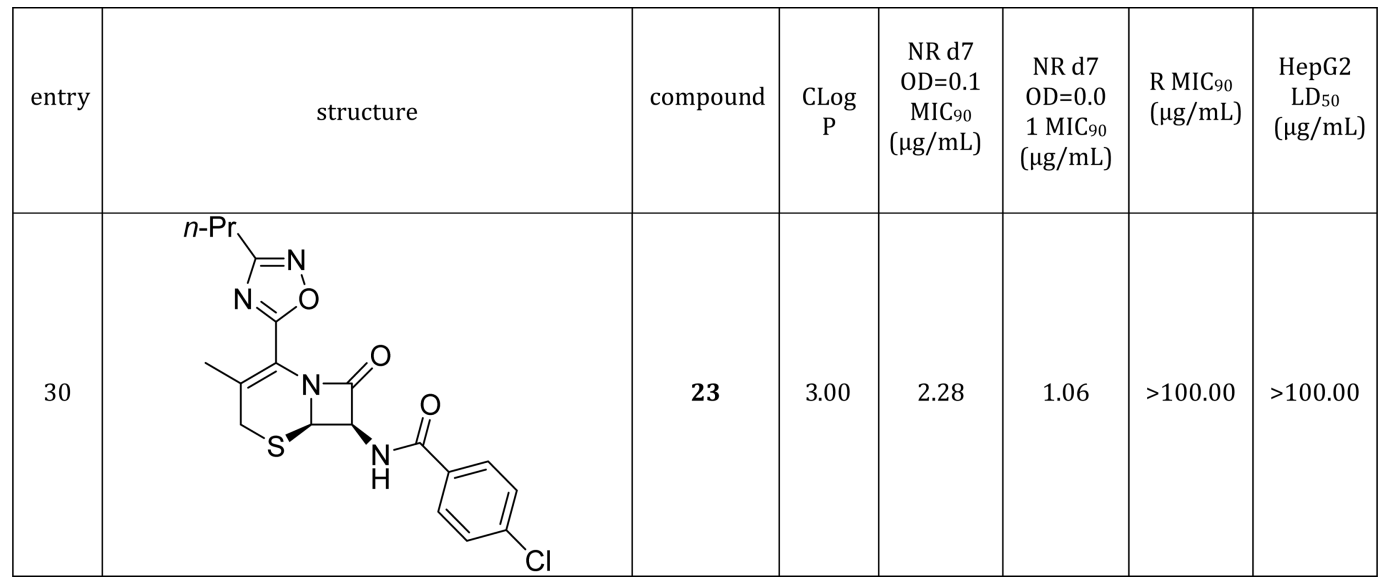

${ }^{a_{\text {These data }}}$ were from a 3-day exposure to compound. ${ }^{b}$ n.d. $=$ not determined. n.t. $=$ not tested.

Table 6. Predicted Properties of Representative C-2 Ester and Oxadiazole Cephalosporins ${ }^{a}$

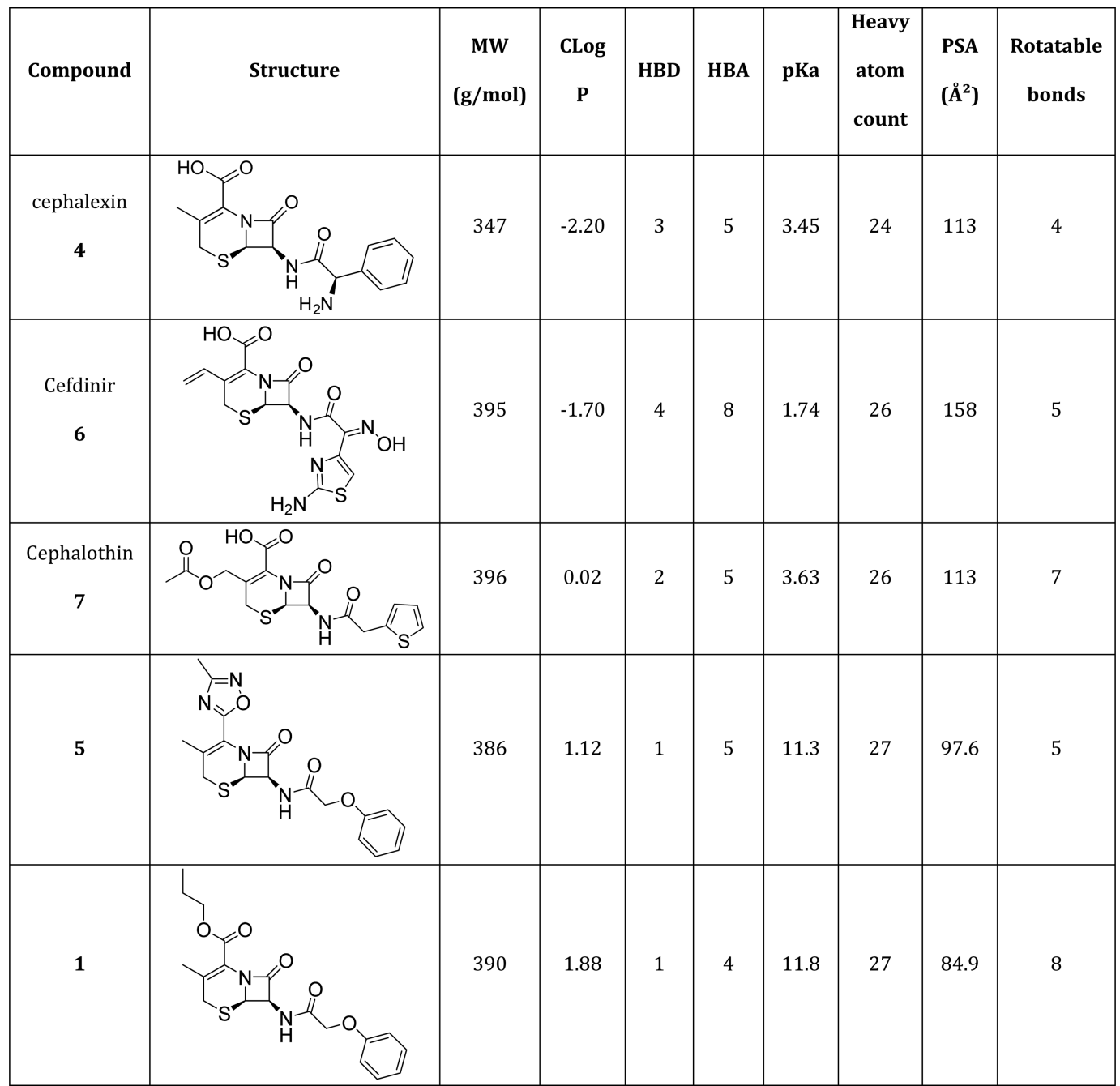

${ }^{a} \mathrm{MW}$, molecular weight; HDB, H-bond donor; HBA, H-bond acceptor; PSA, polar surface area.

remove the urea. To the filtrate was then added ethylamidoxime (411.0 mg, $5.6 \mathrm{mmol}$ ) in $\mathrm{CH}_{2} \mathrm{Cl}_{2}(7 \mathrm{~mL})$, and the mixture was stirred at $\mathrm{rt}$ for $4 \mathrm{~h}$. The mixture was then washed twice with sat. aq $\mathrm{NaHCO}_{3}$, filtered, and concentrated. The residue was then placed in a vacuum oven at $110{ }^{\circ} \mathrm{C}$ for $16 \mathrm{~h}$, and the resulting residue was purified via MPLC (silica, $100 \%$ hexanes $\rightarrow 60 \% \mathrm{EtOAc} /$ hexanes) to afford the title compound as an orange solid (703.2 mg, $52 \%$ yield). $[\alpha]_{\mathrm{D}}{ }^{24}+79.6$ (c 0.72, $\mathrm{CH}_{2} \mathrm{Cl}_{2}$ ); IR (film) $\nu_{\max } 1775,1493,1331,1216,754,732,690$ $\mathrm{cm}^{-1}$; ${ }^{1} \mathrm{H} \mathrm{NMR}\left(400 \mathrm{MHz}, \mathrm{CDCl}_{3}\right) \delta 7.35(\mathrm{~m}, 3 \mathrm{H}), 7.06(\mathrm{tt}, J=7.4$, $1.0 \mathrm{~Hz}, 1 \mathrm{H}), 6.96(\mathrm{~m}, 2 \mathrm{H}), 5.95(\mathrm{dd}, J=9.1,4.8 \mathrm{~Hz}, 1 \mathrm{H}), 5.16(\mathrm{~d}, J=$ $4.7 \mathrm{~Hz}, 1 \mathrm{H}), 4.60(\mathrm{~s}, 2 \mathrm{H}), 3.61(\mathrm{~d}, J=18.4 \mathrm{~Hz}, 1 \mathrm{H}), 3.35(\mathrm{~d}, J=18.3$ $\mathrm{Hz}, 1 \mathrm{H}), 2.49$ (s, 3H), 2.25 (s, 3H); $\left.{ }^{13} \mathrm{C} \mathrm{NMR} \mathrm{(126} \mathrm{MHz,} \mathrm{CDCl}_{3}\right) \delta$ 
Table 7. Stability and Solubility of 4,1 , and 5

\begin{tabular}{|c|c|c|c|}
\hline & cephalexin 4 & 1 & 5 \\
\hline pH 2 stability $(\%)^{a}$ & 73.7 & 110 & 102 \\
\hline pH 7 stability $(\%)^{a}$ & 102 & 133 & 101 \\
\hline pH 12 stability $(\%)^{a}$ & 0.000 & 0.000 & 0.000 \\
\hline solubility $(\mu \mathrm{M} / \mathrm{pH} 7.4)^{b}$ & 75.8 & 22.7 & 83.7 \\
\hline
\end{tabular}

${ }^{a}$ Percent remaining after a $4 \mathrm{~h}$ incubation at $37^{\circ} \mathrm{C} .{ }^{b}$ Determined after shaking at room temperature for $4 \mathrm{~h}$.

Table 8. Preliminary Pharmacokinetic Properties of 4, 1, and 5

\begin{tabular}{|c|c|c|c|}
\hline & cephalexin 4 & 1 & 5 \\
\hline PAMPA (mean $\operatorname{Pe}\left(10^{-6}\right) \mathrm{cm} / \mathrm{s}$ ) & $<0.0001^{a}$ & 7.28 & 13.4 \\
\hline PAMPA $(\log$ Pe $)$ & $<-9.99$ & -5.15 & -4.87 \\
\hline $\begin{array}{l}\text { mouse liver microsomes }\left(t_{1 / 2} \text {, }\right. \\
\text { minutes })^{b}\end{array}$ & stable ${ }^{c}$ & $<5$ & $<5$ \\
\hline $\begin{array}{l}\text { mouse liver microsomes } \mathrm{CL}_{\text {int }} \\
(\mu \mathrm{L} / \mathrm{min} / \mathrm{mg} \text { protein })^{b}\end{array}$ & stable & $\begin{array}{l}\text { unable to } \\
\text { calculate }^{b}\end{array}$ & $\begin{array}{l}\text { unable to } \\
\text { calculate }^{b}\end{array}$ \\
\hline $\begin{array}{l}\text { human liver microsomes }\left(t_{1 / 2}\right. \\
\text { minutes })\end{array}$ & stable & 86.1 & 76.3 \\
\hline $\begin{array}{l}\text { human liver microsomes, } \mathrm{CL}_{\text {int }} \\
(\mu \mathrm{L} / \mathrm{min} / \mathrm{mg} \text { protein })\end{array}$ & stable & 8.07 & 9.13 \\
\hline
\end{tabular}

${ }^{a}$ No compound detected. ${ }^{b}$ Both compounds $\mathbf{1}$ and $\mathbf{5}$ unstable in assay conditions. ${ }^{c}$ No metabolism observed at $\leq 60 \mathrm{~min}$.
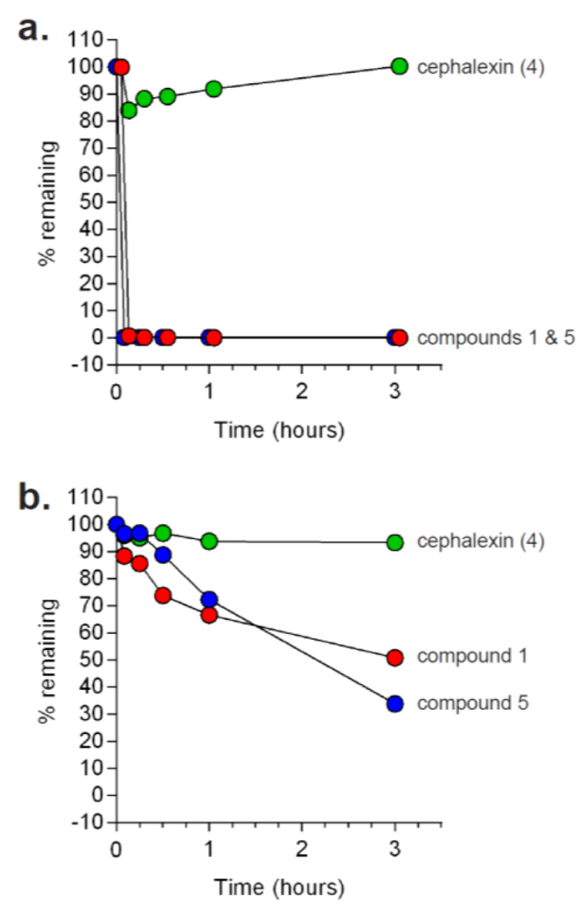

Figure 4. Stability of compounds 1 and 5 in plasma. Compounds 1, 5, and cephalexin (4) were tested for stability in mouse (a) and human (b) plasma at the indicated time points. Stability was inferred by monitoring the parent ion. One of two similar experiments. Compound 1 was tested once in human plasma.

$168.79,167.63,164.56,156.99,130.93,129.98,122.56,117.45,114.90$, 67.25, 58.73, 57.25, 30.02, 20.40, 11.92. HRMS (ESI-TOF) calcd for $\mathrm{C}_{18} \mathrm{H}_{19} \mathrm{~N}_{4} \mathrm{O}_{4} \mathrm{~S}^{+}[\mathrm{M}+\mathrm{H}]^{+}$387.1122, found 387.1088.

Strains and Growth Conditions. Mycobacterial strains and media were prepared as described. ${ }^{21,35}$ Briefly, wild-type $M$. tuberculosis $\mathrm{H} 37 \mathrm{Rv}$ was cultivated at $20 \% \mathrm{O}_{2}$ and $5 \% \mathrm{CO}_{2}$ in Middlebrook $7 \mathrm{H} 9$ bacteriologic medium containing $0.2 \%$ glycerol, tyloxapol $(0.02 \%)$, and $10 \%$ OADC supplement, and the M. tuberculosis strain $\mathrm{mc}^{2} 6220$ $(\Delta \text { panCD } \operatorname{lys} A)^{38,57}$ was grown in similar medium with minor

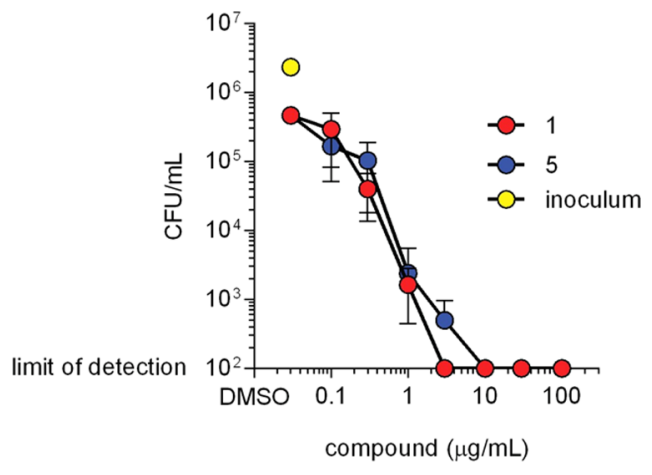

Figure 5. Bactericidal activity of compounds $\mathbf{1}$ and $\mathbf{5}$ for nonreplicating $M$. tuberculosis. Nonreplicating wild-type $M$. tuberculosis at an $\mathrm{OD}_{580}$ of 0.01 was exposed to compounds for 7 days, and surviving bacilli were enumerated on 7H11-OADC agar plates. The inoculum is shown in yellow. The limit of detection was 1 colony arising from 10 $\mu \mathrm{L}$ of undiluted sample. Error bars represent standard deviations of triplicates. One of two similar experiments.

modifications: additional glycerol (final: $0.5 \%$ ), OADC supplement, casamino acids $(0.05 \%)$, L-lysine $(240 \mu \mathrm{g} / \mathrm{mL})$, and pantothenate $(24$ $\mu \mathrm{g} / \mathrm{mL}$ ). Cells were rendered nonreplicating at $1 \% \mathrm{O}_{2}$ and $5 \% \mathrm{CO}_{2}$ in a Sauton's-based medium (per liter: $0.5 \mathrm{~g}$ of $\mathrm{KH}_{2} \mathrm{PO}_{4}, 0.5 \mathrm{~g}$ of $\mathrm{MgSO}_{4}$, $0.05 \mathrm{~g}$ of ferric ammonium citrate, BSA $(0.5 \%), \mathrm{NaCl}(0.085 \%)$, tyloxapol $(0.02 \%)$, L-lysine $(240 \mu \mathrm{g} / \mathrm{mL})$, pantothenate $(24 \mu \mathrm{g} / \mathrm{mL})$, butyrate $(0.05 \%)$, and $0.5 \mathrm{mM} \mathrm{NaNO})_{2}$ ).

High Throughput Screen. Molecules from the University of Kansas in-house library were screened using a reported protocol ${ }^{21,35}$ with minor modifications. For the replicating screen, $500 \mathrm{~nL}$ test agent was added to $50 \mu \mathrm{L}$ of replicating M. tuberculosis $\mathrm{mc}^{2} 6220$ at an $\mathrm{OD}_{580}$ $=0.01$, giving a final concentration of $20 \mu \mathrm{g} / \mathrm{mL}$ and $1 \%$ DMSO. After 7 days of incubation at $20 \% \mathrm{O}_{2}$ and $5 \% \mathrm{CO}_{2}$, the $\mathrm{OD}_{580}$ was determined. For the nonreplicating screen, M. tuberculosis $\mathrm{mc}^{2} 6220$ was washed $2 \times$ in PBS containing tyloxapol (0.02\%; PBS-Tyl) and resuspended in nonreplicating medium containing $0.5 \mathrm{mM} \mathrm{NaNO}$, and $15 \mu \mathrm{L}$ of cells were dispensed into 384-well tissue culture plates (Greiner, reference 781091). Cells were exposed to $150 \mathrm{~nL}$ of test compounds in DMSO, and plates were incubated for 7 days at $1 \% \mathrm{O}_{2}$ and $5 \% \mathrm{CO}_{2}$. After 3 days of exposure to test agents, M. tuberculosis in each well was diluted 5-fold by the addition of $60 \mu \mathrm{L}$ of fresh replicating medium using a reagent dispenser (ThermoScientific), which also served to mix cells. After 7 days of outgrowth at $20 \% \mathrm{O}_{2}$ and $5 \% \mathrm{CO}_{2}$, the $\mathrm{OD}_{580}$ was determined. Primary screening hits and downstream assay data were managed using the CDD Vault from Collaborative Drug Discovery (Burlingame, CA. www. collaborativedrug.com) $)^{58}$ and JChem for Excel and MarvinView (ChemAxon).

Activity against Replicating and Nonreplicating $M$. tuberculosis. For minimal inhibitory concentration (MIC) assays, compounds were serially diluted 2-fold in DMSO from 10 to 0.04 $\mathrm{mM}$ using a PerkinElmer Janus robot with a P30 row/column MDT head to make $100 \times$ compound source stocks in Greiner compound plates (384-well small volume conical well, reference number 784201). Compounds were then distributed into 384-well replicating and nonreplicating assays with $M$. tuberculosis $\mathrm{mc}^{2} 6220$ in 384-well microplates as described above. For colony forming unit assays, experiments were set up using wild-type $M$. tuberculosis single cell suspensions in 96-well tissue culture-treated plates (Corning). At select time points, aliquots of cells were serially diluted in PBS-Tyl and spread on Middlebrook 7H11 agar plates containing a 10\% OADC supplement. Colonies were enumerated $\sim 3$ weeks postplating. The minimal bacteriocidal concentration leading to $99 \%$ reduction in colony forming units $\left(\mathrm{MBC}_{99}\right)$ was extrapolated from $\mathrm{CFU}$ data.

HepG2 Toxicity Assays. Toxicity assays using the human hepatoma cell line HepG2 were as described. ${ }^{59}$ Briefly, HepG2 cells were propagated in Dulbecco's modified Eagle medium (DMEM) containing $10 \%$ fetal bovine serum (FBS), pyruvate, glutamine, and 
a.
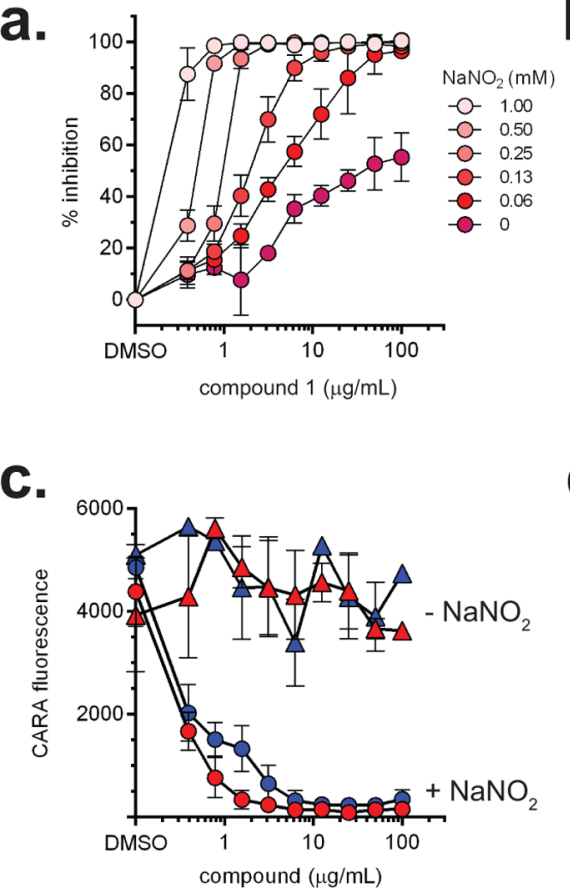

b.
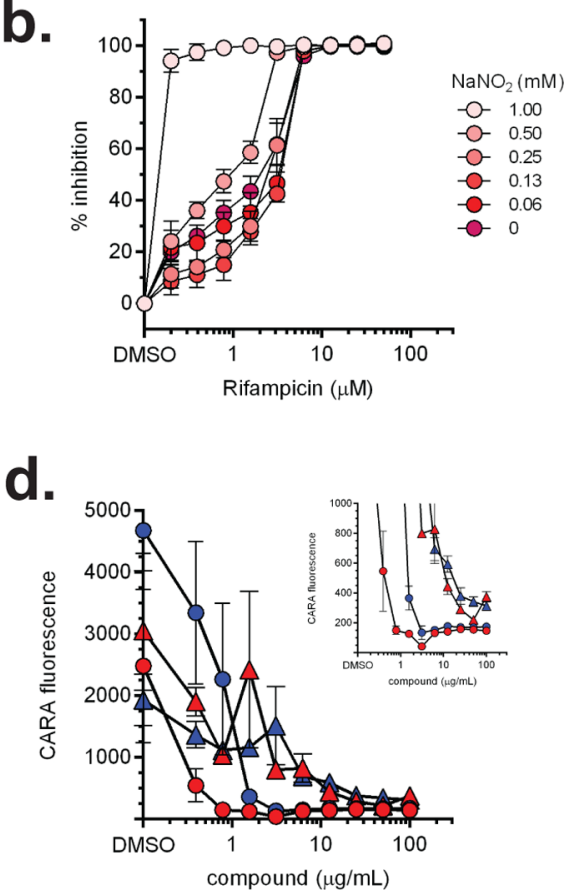

Figure 6. Potentiation of activity of cephalosporins against nonreplicating $M$. tuberculosis by reactive nitrogen species. Wild-type M. tuberculosis was resuspended at an $\mathrm{OD}_{580}$ of 0.1 in nonreplicating medium containing indicated concentrations of $\mathrm{NaNO}_{2}(0-1 \mathrm{mM})$ and dispensed into separate microtiter plates for each $\mathrm{NaNO}_{2}$ concentration. Cells were then exposed to (a) 1 or (b) rifampicin for 7 days, after which a standard outgrowth assay was initiated to estimate the number of surviving cells. In a separate experiment, nonreplicating M. tuberculosis at a standard $\mathrm{OD}_{580}$ of $(\mathrm{c}) 0.1$ or lower inoculum of $\mathrm{OD}_{580}$ of (d) 0.01 were treated with either $\mathbf{1}$ (red) or 5 (blue) in the presence or absence of $0.5 \mathrm{mM} \mathrm{NaNO}_{2}$ for 7 days. CARA fluorescence provides an estimate of mycobacterial viability; complete loss of fluorescence is associated with $\geq 2-3 \log _{10}$ CFU reduction.

a.

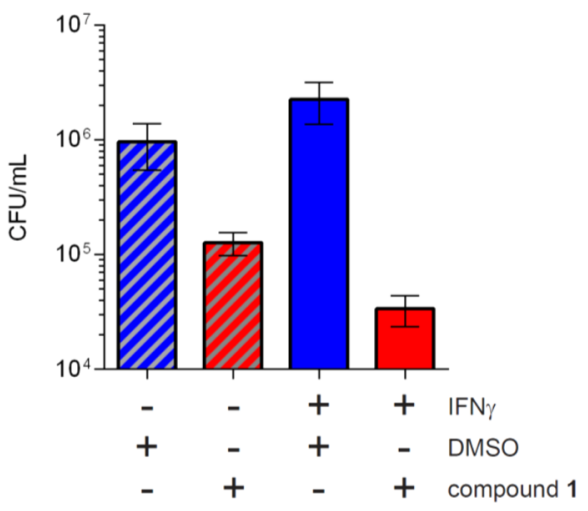

b.

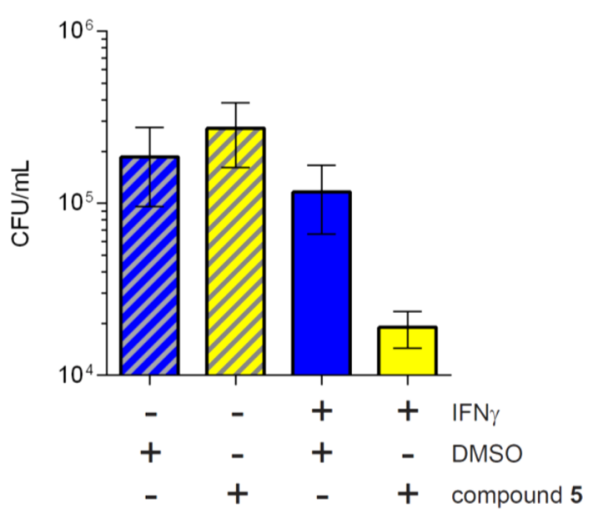

Figure 7. Bactericidal activity of (a) 1 and (b) 5 against intracellular M. tuberculosis. Mouse bone marrow-derived macrophages activated or not with $50 \mathrm{ng} / \mathrm{mL}$ of IFN $\gamma$ were infected with wild-type $M$. tuberculosis. After a $4 \mathrm{~h}$ period for bacterial uptake, macrophages were washed and treated with $100 \mu \mathrm{g} / \mathrm{mL}$ of 1 or 5 for (a) 4 or (b) 3 days. Morphology of the macrophages was not affected by addition of 1 or 5 at the concentrations shown. One of five similar experiments.

nonessential amino acids. HepG2 cells were incubated for 2 days with DMSO vehicle control or test compounds ( $\leq 1 \%$ DMSO final) at 3000 cells/well in 384-well tissue culture plates (Greiner reference 781091). Cellular viability was determined after 2 days by measuring ATP content with a CellTiter-Glo kit (Promega).

Microbial Spectrum. Select compounds were tested for activity against a panel of replicating Gram positive and Gram negative bacteria (Mycobacterium smegmatis, Staphylococcus aureus, Escherichia coli, and Pseudomonas aeruginosa) and yeast (Candida albicans). Bacteriologic medium and assay conditions were as described. ${ }^{21}$ In brief, $200 \mu \mathrm{L}$ of cells at an $\mathrm{OD}_{580}$ of 0.01 in a sterile, clear tissue culture-treated Corning 96-well plate were exposed to DMSO or drug, and growth was determined by optical density.
Stability Assay. Compounds were dissolved at $50 \mu \mathrm{g} / \mathrm{mL}$ in cellfree PBS ( $\mathrm{pH} 7.4$ ) or cell-free nonreplicating medium ( $\mathrm{pH}$ 5.0) containing or not $0.5 \mathrm{mM} \mathrm{NaNO}$. Poorly soluble compounds were dissolved at $5 \mu \mathrm{g} / \mathrm{mL}$ and in a 50:50 (vol:vol) solution of acetonitrile and PBS, or acetonitrile and nonreplicating medium containing or not $0.5 \mathrm{mM} \mathrm{NaNO}$. The nonreplicating medium was as described above except that BSA, tyloxapol, lysine, and pantothenate were omitted. Solutions containing acetonitrile had their $\mathrm{pH}$ adjusted to 5.0 (the additional acetonitrile increased the $\mathrm{pH}$ from 5.0 to 5.8). Samples were incubated at $37^{\circ} \mathrm{C}$, and aliquots were removed every $12 \mathrm{~h}$ for analysis by LC-MS. Data represent percent remaining of the parent compound compared to that at the start of the experiment.

Cheminformatics. Tanimoto similarity between molecules and cheminformatic analysis of chemical properties (including ClogP 
values) were determined in Collaborative Drug Discovery (CCD) (Burlingame, CA; www.collaborativedrug.com) $)^{58}$ using ChemAxon software.

Physicochemical, Permeability, and Metabolism Studies. These assays were performed by BioDuro (Shanghai, China). Mouse and human liver microsomal stability was assayed in triplicate at 0,15 , 30,45 , and $60 \mathrm{~min}$.

Plasma Stability. Cephalosporins 1, 5, and cephalexin were spiked into lithium heparin-treated human and CD-1 mouse plasma (bioreclammation) at $1 \mu \mathrm{g} / \mathrm{mL}$. Spiked samples were incubated at $37^{\circ} \mathrm{C}$, and extractions were performed at $5,15,30,60$, and $180 \mathrm{~min}$. The reactions were quenched and proteins precipitated at each time point by adding $20 \mu \mathrm{L}$ of spiked plasma to $200 \mu \mathrm{L}$ of extraction solvent containing methanol/acetonitrile $(1: 1 ; \mathrm{vol} / \mathrm{vol})$ and $10 \mathrm{ng} / \mathrm{mL}$ of verapamil (Toronto Research Chemicals, Inc.) as an internal standard (IS). In addition, $20 \mu \mathrm{L}$ of $1: 1$ acetonitrile/water (ACN/ $\mathrm{H}_{2} \mathrm{O}$; vol/vol) were added. A reference sample was created by adding $20 \mu \mathrm{L}$ of unspiked plasma to $200 \mu \mathrm{L}$ of the extraction solvent. After the plasma enzymes were denatured by the extraction solvent, $20 \mu \mathrm{L}$ of a $1 \mu \mathrm{g} / \mathrm{mL}$ solution in $1: 1 \mathrm{ACN} / \mathrm{H}_{2} \mathrm{O}$ was added to the reference sample. Extracted samples were vortexed for $5 \mathrm{~min}$ and then centrifuged at $3000 \mathrm{rpm}$ for $5 \mathrm{~min}$. Then, $100 \mu \mathrm{L}$ of extract was transferred to $100 \mu \mathrm{L}$ of $\mathrm{ddH}_{2} 0$ for LC-MS analysis. LC-MS analysis was performed with an Agilent 1260 liquid chromatography system coupled to a 4000 Qtrap mass spectrometer (AB Sciex) in multiple reaction monitoring (MRM) mode with positive electrospray ionization (ESI) and an Agilent column, SB-C8, $2.1 \times 30 \mathrm{~mm}, 3.5$ $\mu \mathrm{m}$. Mobile phase A was $0.1 \%$ formic acid in $100 \% \mathrm{H}_{2} \mathrm{O}$, and mobile phase B was $0.1 \%$ formic acid in $100 \%$ acetonitrile. Injection volumes were routinely $2 \mu \mathrm{L}$. The ions monitored were compound $\mathbf{1}(\mathrm{m} / \mathrm{z}$ 387.1/195.9), compound 5 (391.1/199.9), cephalexin (348.1/158.1), and verapamil (455.4/165.2). The percentage remaining was determined at each time point by dividing the sample analyte/IS peak area ratio by the reference sample analyte/IS peak area ratio.

Charcoal Agar Resazurin Assay (CARA). The CARA was used as described. ${ }^{42}$ In brief, $10 \mu \mathrm{L}$ aliquots from replicating or nonreplicating $\mathrm{MIC}_{90}$ assay plates were removed and spotted onto microplates containing $200 \mu \mathrm{L}$ of 7H11-OADC-charcoal agar in each well. The microplates were then incubated for $7-10$ days at $37{ }^{\circ} \mathrm{C}$ at $20 \% \mathrm{O}_{2}$ and $5 \% \mathrm{CO}_{2}$. The film of bacterial growth (microcolonies) on the microplates was semiquantitated by the addition of $40 \mu \mathrm{L}$ of a $1: 1$ (v/ $\mathrm{v})$ mixture of Alamar blue (AB) and Tween 80 (TW80) and $1 \mathrm{~h}$ of further incubation at $37{ }^{\circ} \mathrm{C}$ at $20 \% \mathrm{O}_{2}$ and $5 \% \mathrm{CO}_{2}$. In some cases, if the CARA microplate appeared dry, all wells were prewetted with 40 $\mu \mathrm{L}$ of PBS prior to the addition of the AB:TW80 developing solution. Fluorescence was determined by top-read with excitation at $530 \mathrm{~nm}$ and emission at $590 \mathrm{~nm}$. The CARA-minimal bactericidal concentration leading to $\geq 99 \%$ loss in CFUs (CARA-MBC ${ }_{>99}$ ) was estimated as the lowest concentration of drug leading to complete loss of Alamar blue fluorescence.

Macrophage Infections. Primary bone marrow-derived macrophage infections were performed as described. ${ }^{17,60-62}$ In brief, $\sim 1 \times$ $10^{5}$ macrophages isolated from 8-week old female C57Bl6 mice were grown in 48-well plates in DMEM supplemented with $4.5 \mathrm{~g} / \mathrm{L}$ of glucose, $0.584 \mathrm{~g} / \mathrm{L}$ of L-glutamine, $1 \mathrm{mM}$ pyruvate, $10 \% \mathrm{FBS}$, and $10 \%$ L-cell conditioned medium containing or not $50 \mathrm{ng} / \mathrm{mL}$ of recombinant mouse IFN $\gamma$ and infected with wild-type $M$. tuberculosis $\mathrm{H} 37 \mathrm{Rv}$ at a multiplicity of infection of $1-5$. Log phase wild-type $M$. tuberculosis was allowed to infect macrophages for $4 \mathrm{~h}$, after which medium and extracellular $M$. tuberculosis were removed by two washes with PBS and replaced with fresh medium containing compounds or not at $1 \%$ DMSO. At the times indicated, macrophages were washed and lysed with PBS supplemented with $0.5 \%$ Triton X-100. Surviving bacilli were enumerated on 7H11-OADC agar plates. Macrophage supernatants were assayed for nitrite with the Greiss assay.

\section{ASSOCIATED CONTENT}

\section{Supporting Information}

The Supporting Information is available free of charge on the ACS Publications website at DOI: 10.1021/acs.jmedchem.5b01833.

Experimental and analytical details for synthetic analogues and copies of ${ }^{1} \mathrm{H}$ and ${ }^{13} \mathrm{C}$ NMR spectra (PDF)

\section{AUTHOR INFORMATION}

\section{Corresponding Authors}

*Phone: 212-746-6505; e-mail: cnathan@med.cornell.edu.

*Phone: 919-966-9650; e-mail: jaube@unc.edu.

\section{Notes}

The authors declare no competing financial interest.

\section{ACKNOWLEDGMENTS}

We thank S. Brickner (S.J. Brickner Consulting, LLC, Ledyard, CT), A. Mendoza-Losana, D. Barros, R. Bates, and L. Ballell (GlaxoSmithKline, Tres Cantos, Spain) and K. Burns-Huang and K. Rhee (Weill Cornell Medical College) for insightful discussions and suggestions. We thank F. Kaya (Public Health Research Institute, New Jersey Medical School, Rutgers, the State University of New Jersey, Newark, NJ) for assistance with plasma stability assays, and J. Glasheen (Weill Cornell Medical College) for work that will be reported elsewhere. This work was supported by the TB Drug Accelerator of the Bill and Melinda Gates Foundation, the Abby and Howard P. Milstein Program in Chemical Biology and Translational Medicine, the National Institute of General Medical Sciences (P50GM069663), the National Human Genome Research Institute (KU Specialized Chemistry Center, U54 HG005031), and an NIH TB Research Unit (U19 AI111143). S.S.K. was supported by NIH grant K08AI108799. The Department of Microbiology and Immunology is supported by the William Randolph Hearst Foundation. We acknowledge the Medicinal Chemistry Core of the COBRE Center for Cancer Therapeutics at the University of Kansas (NIH RR030926) for supplying the original library of cephalosporin esters.

\section{DEDICATION}

IIDedicated to the memory of Lester A. Mitscher

\section{ABBREVIATIONS USED}

$\mathrm{AB}$, Alamar blue; ACN, acetonitrile; 7-ADCA, 7-aminodeacetoxycephalosporanic acid; CARA, charcoal agar resazurin assay (CFU-surrogate assay); CDD, collaborative drug discovery; CFU, colony-forming unit; DlaT, dihydrolipoamide acyltransferase; DMEM, Dulbecco's modified eagle medium; IFN $\gamma$, interferon $\gamma$; IS, internal standard; LDT, L,D-transpeptidase; MDT, modular dispense technology; MRM, multiple reaction monitoring; Mtb, Mycobacterium tuberculosis; NR, nonreplicating; OADC, oleic albumin dextrose catalase; PBSTyl, PBS-containing tyloxapol; R, replicating; RNS, reactive nitrogen species; TW80, Tween 80

\section{REFERENCES}

(1) Lee, M.; Lee, J.; Carroll, M. W.; Choi, H.; Min, S.; Song, T.; Via, L. E.; Goldfeder, L. C.; Kang, E.; Jin, B.; Park, H.; Kwak, H.; Kim, H.; Jeon, H. S.; Jeong, I.; Joh, J. S.; Chen, R. Y.; Olivier, K. N.; Shaw, P. A.; Follmann, D.; Song, S. D.; Lee, J. K.; Lee, D.; Kim, C. T.; Dartois, V.; Park, S. K.; Cho, S. N.; Barry, C. E., 3rd. Linezolid for treatment of 
chronic extensively drug-resistant tuberculosis. N. Engl. J. Med. 2012, $367,1508-1518$.

(2) Diacon, A. H.; Pym, A.; Grobusch, M.; Patientia, R.; Rustomjee, R.; Page-Shipp, L.; Pistorius, C.; Krause, R.; Bogoshi, M.; Churchyard, G.; Venter, A.; Allen, J.; Palomino, J. C.; De Marez, T.; van Heeswijk, R. P.; Lounis, N.; Meyvisch, P.; Verbeeck, J.; Parys, W.; de Beule, K.; Andries, K.; Mc Neeley, D. F. The diarylquinoline TMC207 for multidrug-resistant tuberculosis. N. Engl. J. Med. 2009, 360, 23972405.

(3) Stover, C. K.; Warrener, P.; VanDevanter, D. R.; Sherman, D. R.; Arain, T. M.; Langhorne, M. H.; Anderson, S. W.; Towell, J. A.; Yuan, Y.; McMurray, D. N.; Kreiswirth, B. N.; Barry, C. E.; Baker, W. R. A small-molecule nitroimidazopyran drug candidate for the treatment of tuberculosis. Nature 2000, 405, 962-966.

(4) Nathan, C. Fresh approaches to anti-infective therapies. Sci. Transl. Med. 2012, 4, 140sr2.

(5) Bigger, J. Treatment of staphylococcal infections with penicillin by intermittent sterilisation. Lancet 1944, 244, 497-500.

(6) Wakamoto, Y.; Dhar, N.; Chait, R.; Schneider, K.; SignorinoGelo, F.; Leibler, S.; McKinney, J. D. Dynamic persistence of antibiotic-stressed mycobacteria. Science 2013, 339, 91-95.

(7) Orman, M. A.; Brynildsen, M. P. Dormancy is not necessary or sufficient for bacterial persistence. Antimicrob. Agents Chemother. 2013, $57,3230-3239$.

(8) Balaban, N. Q.; Merrin, J.; Chait, R.; Kowalik, L.; Leibler, S. Bacterial persistence as a phenotypic switch. Science 2004, 305, 16221625 .

(9) Javid, B.; Sorrentino, F.; Toosky, M.; Zheng, W.; Pinkham, J. T.; Jain, N.; Pan, M.; Deighan, P.; Rubin, E. J. Mycobacterial mistranslation is necessary and sufficient for rifampicin phenotypic resistance. Proc. Natl. Acad. Sci. U. S. A. 2014, 111, 1132-1137.

(10) Karakousis, P. C.; Yoshimatsu, T.; Lamichhane, G.; Woolwine, S. C.; Nuermberger, E. L.; Grosset, J.; Bishai, W. R. Dormancy phenotype displayed by extracellular Mycobacterium tuberculosis within artificial granulomas in mice. J. Exp. Med. 2004, 200, 647-657.

(11) Wayne, L. G.; Hayes, L. G. An in vitro model for sequential study of shiftdown of Mycobacterium tuberculosis through two stages of nonreplicating persistence. Infect. Immun. 1996, 64, 2062-2069.

(12) Xie, Z.; Siddiqi, N.; Rubin, E. J. Differential antibiotic susceptibilities of starved Mycobacterium tuberculosis isolates. Antimicrob. Agents Chemother. 2005, 49, 4778-4780.

(13) MacMicking, J. D.; North, R. J.; LaCourse, R.; Mudgett, J. S.; Shah, S. K.; Nathan, C. F. Identification of nitric oxide synthase as a protective locus against tuberculosis. Proc. Natl. Acad. Sci. U. S. A. 1997, 94, 5243-5248.

(14) MacMicking, J. D.; Taylor, G. A.; McKinney, J. D. Immune control of tuberculosis by IFN-gamma-inducible LRG-47. Science 2003, 302, 654-659.

(15) Schnappinger, D.; Ehrt, S.; Voskuil, M. I.; Liu, Y.; Mangan, J. A.; Monahan, I. M.; Dolganov, G.; Efron, B.; Butcher, P. D.; Nathan, C.; Schoolnik, G. K. Transcriptional Adaptation of Mycobacterium tuberculosis within Macrophages: Insights into the Phagosomal Environment. J. Exp. Med. 2003, 198, 693-704.

(16) Mattila, J. T.; Ojo, O. O.; Kepka-Lenhart, D.; Marino, S.; Kim, J. H.; Eum, S. Y.; Via, L. E.; Barry, C. E., 3rd; Klein, E.; Kirschner, D. E.; Morris, S. M., Jr.; Lin, P. L.; Flynn, J. L. Microenvironments in tuberculous granulomas are delineated by distinct populations of macrophage subsets and expression of nitric oxide synthase and arginase isoforms. J. Immunol. 2013, 191, 773-784.

(17) Bryk, R.; Gold, B.; Venugopal, A.; Singh, J.; Samy, R.; Pupek, K.; Cao, H.; Popescu, C.; Gurney, M.; Hotha, S.; Cherian, J.; Rhee, K.; Ly, L.; Converse, P. J.; Ehrt, S.; Vandal, O.; Jiang, X.; Schneider, J.; Lin, G.; Nathan, C. Selective killing of nonreplicating mycobacteria. Cell Host Microbe 2008, 3, 137-145.

(18) Darby, C. M.; Ingolfsson, H. I.; Jiang, X.; Shen, C.; Sun, M.; Zhao, N.; Burns, K.; Liu, G.; Ehrt, S.; Warren, J. D.; Anderson, O. S.; Brickner, S. J.; Nathan, C. Whole cell screen for inhibitors of $\mathrm{pH}$ homeostasis in Mycobacterium tuberculosis. PLoS One 2013, 8, e68942.
(19) Grant, S. S.; Kawate, T.; Nag, P. P.; Silvis, M. R.; Gordon, K.; Stanley, S. A.; Kazyanskaya, E.; Nietupski, R.; Golas, A.; Fitzgerald, M.; Cho, S.; Franzblau, S. G.; Hung, D. T. Identification of novel inhibitors of nonreplicating Mycobacterium tuberculosis using a carbon starvation model. ACS Chem. Biol. 2013, 8, 2224-2234.

(20) Mak, P. A.; Rao, S. P.; Ping Tan, M.; Lin, X.; Chyba, J.; Tay, J.; Ng, S. H.; Tan, B. H.; Cherian, J.; Duraiswamy, J.; Bifani, P.; Lim, V.; Lee, B. H.; Ling, M. N.; Beer, D.; Thayalan, P.; Kuhen, K.; Chatterjee, A.; Supek, F.; Glynne, R.; Zheng, J.; Boshoff, H. I.; Barry, C. E., 3rd; Dick, T.; Pethe, K.; Camacho, L. R. A high-throughput screen to identify inhibitors of ATP homeostasis in non-replicating Mycobacterium tuberculosis. ACS Chem. Biol. 2012, 7, 1190-1197.

(21) Gold, B.; Pingle, M.; Brickner, S. J.; Shah, N.; Roberts, J.; Rundell, M.; Bracken, W. C.; Warrier, T.; Somersan, S.; Venugopal, A.; Darby, C.; Jiang, X.; Warren, J. D.; Fernandez, J.; Ouerfelli, O.; Nuermberger, E. L.; Cunningham-Bussel, A.; Rath, P.; Chidawanyika, T.; Deng, H.; Realubit, R.; Glickman, J. F.; Nathan, C. F. Nonsteroidal anti-inflammatory drug sensitizes Mycobacterium tuberculosis to endogenous and exogenous antimicrobials. Proc. Natl. Acad. Sci. U. S. A. 2012, 109, 16004-16011.

(22) Lee, R. E.; Hurdle, J. G.; Liu, J.; Bruhn, D. F.; Matt, T.; Scherman, M. S.; Vaddady, P. K.; Zheng, Z.; Qi, J.; Akbergenov, R.; Das, S.; Madhura, D. B.; Rathi, C.; Trivedi, A.; Villellas, C.; Lee, R. B.; Rakesh; Waidyarachchi, S. L.; Sun, D.; McNeil, M. R.; Ainsa, J. A.; Boshoff, H. I.; Gonzalez-Juarrero, M.; Meibohm, B.; Bottger, E. C.; Lenaerts, A. J. Spectinamides: a new class of semisynthetic antituberculosis agents that overcome native drug efflux. Nat. Med. 2014, 20, 152-158.

(23) Wang, F.; Sambandan, D.; Halder, R.; Wang, J.; Batt, S. M.; Weinrick, B.; Ahmad, I.; Yang, P.; Zhang, Y.; Kim, J.; Hassani, M.; Huszar, S.; Trefzer, C.; Ma, Z.; Kaneko, T.; Mdluli, K. E.; Franzblau, S.; Chatterjee, A. K.; Johnsson, K.; Mikusova, K.; Besra, G. S.; Futterer, K.; Robbins, S. H.; Barnes, S. W.; Walker, J. R.; Jacobs, W. R., Jr.; Schultz, P. G. Identification of a small molecule with activity against drug-resistant and persistent tuberculosis. Proc. Natl. Acad. Sci. U. S. A. 2013, 110, E2510-E2517.

(24) Darby, C. M.; Nathan, C. F. Killing of non-replicating Mycobacterium tuberculosis by 8-hydroxyquinoline. J. Antimicrob. Chemother. 2010, 65, 1424-1427.

(25) de Carvalho, L. P.; Lin, G.; Jiang, X.; Nathan, C. Nitazoxanide kills replicating and nonreplicating Mycobacterium tuberculosis and evades resistance. J. Med. Chem. 2009, 52, 5789-5792.

(26) Fera, D.; Schultz, D. C.; Hodawadekar, S.; Reichman, M.; Donover, P. S.; Melvin, J.; Troutman, S.; Kissil, J. L.; Huryn, D. M.; Marmorstein, R. Identification and characterization of small molecule antagonists of $\mathrm{pRb}$ inactivation by viral oncoproteins. Chem. Biol. 2012, 19, 518-528.

(27) Cho, S. H.; Warit, S.; Wan, B.; Hwang, C. H.; Pauli, G. F.; Franzblau, S. G. Low-oxygen-recovery assay for high-throughput screening of compounds against nonreplicating Mycobacterium tuberculosis. Antimicrob. Agents Chemother. 2007, 51, 1380-1385.

(28) Hartkoorn, R. C.; Ryabova, O. B.; Chiarelli, L. R.; Riccardi, G.; Makarov, V.; Cole, S. T. Mechanism of action of 5-nitrothiophenes against Mycobacterium tuberculosis. Antimicrob. Agents Chemother. 2014, $58,2944-2947$.

(29) Sala, C.; Dhar, N.; Hartkoorn, R. C.; Zhang, M.; Ha, Y. H.; Schneider, P.; Cole, S. T. Simple model for testing drugs against nonreplicating Mycobacterium tuberculosis. Antimicrob. Agents Chemother. 2010, 54, 4150-4158.

(30) Zhang, M.; Sala, C.; Hartkoorn, R. C.; Dhar, N.; MendozaLosana, A.; Cole, S. T. Streptomycin-starved Mycobacterium tuberculosis 18b, a drug discovery tool for latent tuberculosis. Antimicrob. Agents Chemother. 2012, 56, 5782-5789.

(31) Marrero, J.; Rhee, K. Y.; Schnappinger, D.; Pethe, K.; Ehrt, S. Gluconeogenic carbon flow of tricarboxylic acid cycle intermediates is critical for Mycobacterium tuberculosis to establish and maintain infection. Proc. Natl. Acad. Sci. U. S. A. 2010, 107, 9819-9824. 
(32) Munoz-Elias, E. J.; McKinney, J. D. Mycobacterium tuberculosis isocitrate lyases 1 and 2 are jointly required for in vivo growth and virulence. Nat. Med. 2005, 11, 638-644.

(33) Timm, J.; Post, F. A.; Bekker, L. G.; Walther, G. B.; Wainwright, H. C.; Manganelli, R.; Chan, W. T.; Tsenova, L.; Gold, B.; Smith, I.; Kaplan, G.; McKinney, J. D. Differential expression of iron-, carbon-, and oxygen-responsive mycobacterial genes in the lungs of chronically infected mice and tuberculosis patients. Proc. Natl. Acad. Sci. U. S. A. 2003, 100, 14321-14326.

(34) Vandal, O. H.; Pierini, L. M.; Schnappinger, D.; Nathan, C. F.; Ehrt, S. A membrane protein preserves intrabacterial $\mathrm{pH}$ in intraphagosomal Mycobacterium tuberculosis. Nat. Med. 2008, 14, 849-854.

(35) Gold, B.; Warrier, T.; Nathan, C. A Multi-Stress Model for High Throughput Screening Against Non-replicating Mycobacterium tuberculosis. In Mycobacteria Protocols, Methods in Molecular Biology, 3rd ed.; Parish, T., Roberts, D., Eds.; Springer, 2015; Vol. 1285, pp 293-315.

(36) Warrier, T.; Martinez-Hoyos, M.; Marin-Amieva, M.; Colmenarejo, G.; Porras-De Francisco, E.; Alvarez-Pedraglio, A. I.; Fraile-Gabaldon, M. T.; Torres-Gomez, P. A.; Lopez-Quezada, L.; Gold, B.; Roberts, J.; Ling, Y.; Somersan-Karakaya, S.; Little, D.; Cammack, N.; Nathan, C.; Mendoza-Losana, A. Identification of Novel Anti-mycobacterial Compounds by Screening a Pharmaceutical Small-Molecule Library against Nonreplicating Mycobacterium tuberculosis. ACS Infect. Dis. 2015, 1, 580-585.

(37) Liu, C.; Dutta, D.; Mitscher, L. Design and synthesis of new cephalosporin antibiotics. Monatsh. Chem. 2014, 145, 633-638.

(38) Larsen, M. H.; Biermann, K.; Chen, B.; Hsu, T.; Sambandamurthy, V. K.; Lackner, A. A.; Aye, P. P.; Didier, P.; Huang, D.; Shao, L.; Wei, H.; Letvin, N. L.; Frothingham, R.; Haynes, B. F.; Chen, Z. W.; Jacobs, W. R., Jr. Efficacy and safety of live attenuated persistent and rapidly cleared Mycobacterium tuberculosis vaccine candidates in non-human primates. Vaccine 2009, 27, 47094717.

(39) Sambandamurthy, V. K.; Wang, X.; Chen, B.; Russell, R. G.; Derrick, S.; Collins, F. M.; Morris, S. L.; Jacobs, W. R., Jr. A pantothenate auxotroph of Mycobacterium tuberculosis is highly attenuated and protects mice against tuberculosis. Nat. Med. 2002, $8,1171-1174$.

(40) Brook, I. Inoculum effect. Clin. Infect. Dis. 1989, 11, 361-368.

(41) Barth, W. E. 4-(Tetrazol-5-yl)- $\Delta 3$-cephem compounds. US 05/ 658,292, February 17, 1976.

(42) Gold, B.; Roberts, J.; Ling, Y.; Quezada, L. L.; Glasheen, J.; Ballinger, E.; Somersan-Karakaya, S.; Warrier, T.; Warren, J. D.; Nathan, C. Rapid, Semiquantitative Assay To Discriminate among Compounds with Activity against Replicating or Nonreplicating Mycobacterium tuberculosis. Antimicrob. Agents Chemother. 2015, 59, $6521-6538$.

(43) Tuomanen, E. Phenotypic tolerance: the search for beta-lactam antibiotics that kill nongrowing bacteria. Clin. Infect. Dis. 1986, 8 (Suppl 3), S279-S291.

(44) Tuomanen, E.; Cozens, R.; Tosch, W.; Zak, O.; Tomasz, A. The rate of killing of Escherichia coli by beta-lactam antibiotics is strictly proportional to the rate of bacterial growth. Microbiology 1986, 132, 1297-1304.

(45) Hugonnet, J. E.; Tremblay, L. W.; Boshoff, H. I.; Barry, C. E., 3rd; Blanchard, J. S. Meropenem-clavulanate is effective against extensively drug-resistant Mycobacterium tuberculosis. Science 2009, 323, 1215-1218.

(46) Dhar, N.; Dubee, V.; Ballell, L.; Cuinet, G.; Hugonnet, J. E.; Signorino-Gelo, F.; Barros, D.; Arthur, M.; McKinney, J. D. Rapid cytolysis of Mycobacterium tuberculosis by faropenem, an orally bioavailable beta-lactam antibiotic. Antimicrob. Agents Chemother. 2015, 59, 1308-1319.

(47) Tomasz, A.; Waks, S. Mechanism of action of penicillin: triggering of the pneumococcal autolytic enzyme by inhibitors of cell wall synthesis. Proc. Natl. Acad. Sci. U. S. A. 1975, 72, 4162-4166.
(48) Tomasz, A.; Albino, A.; Zanati, E. Multiple antibiotic resistance in a bacterium with suppressed autolytic system. Nature 1970, 227, $138-140$.

(49) Cho, H.; Uehara, T.; Bernhardt, T. G. Beta-lactam antibiotics induce a lethal malfunctioning of the bacterial cell wall synthesis machinery. Cell 2014, 159, 1300-1311.

(50) Lavollay, M.; Arthur, M.; Fourgeaud, M.; Dubost, L.; Marie, A.; Veziris, N.; Blanot, D.; Gutmann, L.; Mainardi, J. L. The peptidoglycan of stationary-phase Mycobacterium tuberculosis predominantly contains cross-links generated by L,D-transpeptidation. J. Bacteriol. 2008, 190, 4360-4366.

(51) Gupta, R.; Lavollay, M.; Mainardi, J. L.; Arthur, M.; Bishai, W. $\mathrm{R}$; Lamichhane, G. The Mycobacterium tuberculosis protein LdtMt2 is a nonclassical transpeptidase required for virulence and resistance to amoxicillin. Nat. Med. 2010, 16, 466-469.

(52) Cordillot, M.; Dubee, V.; Triboulet, S.; Dubost, L.; Marie, A.; Hugonnet, J. E.; Arthur, M.; Mainardi, J. L. In vitro cross-linking of Mycobacterium tuberculosis peptidoglycan by L,D-transpeptidases and inactivation of these enzymes by carbapenems. Antimicrob. Agents Chemother. 2013, 57, 5940-5945.

(53) Paetzel, M.; Dalbey, R. E.; Strynadka, N. C. Crystal structure of a bacterial signal peptidase in complex with a beta-lactam inhibitor. Nature 1998, 396, 186-190.

(54) Sperka, T.; Pitlik, J.; Bagossi, P.; Tozser, J. Beta-lactam compounds as apparently uncompetitive inhibitors of HIV-1 protease. Bioorg. Med. Chem. Lett. 2005, 15, 3086-3090.

(55) Powers, J. C.; Asgian, J. L.; Ekici, O. D.; James, K. E. Irreversible inhibitors of serine, cysteine, and threonine proteases. Chem. Rev. 2002, 102, 4639-4750.

(56) Russell, D. G.; Mwandumba, H. C.; Rhoades, E. E. Mycobacterium and the coat of many lipids. J. Cell Biol. 2002, 158, 421-426.

(57) Sambandamurthy, V. K.; Derrick, S. C.; Jalapathy, K. V.; Chen, B.; Russell, R. G.; Morris, S. L.; Jacobs, W. R., Jr. Long-term protection against tuberculosis following vaccination with a severely attenuated double lysine and pantothenate auxotroph of Mycobacterium tuberculosis. Infect. Immun. 2005, 73, 1196-1203.

(58) Hohman, M.; Gregory, K.; Chibale, K.; Smith, P. J.; Ekins, S.; Bunin, B. Novel web-based tools combining chemistry informatics, biology and social networks for drug discovery. Drug Discovery Today 2009, 14, 261-270.

(59) Zheng, P.; Somersan-Karakaya, S.; Lu, S.; Roberts, J.; Pingle, M.; Warrier, T.; Little, D.; Guo, X.; Brickner, S. J.; Nathan, C. F.; Gold, B.; Liu, G. Synthetic Calanolides with Bactericidal Activity Against Replicating and Nonreplicating Mycobacterium tuberculosis. J. Med. Chem. 2014, 57, 3755-3772.

(60) Shi, S.; Nathan, C.; Schnappinger, D.; Drenkow, J.; Fuortes, M.; Block, E.; Ding, A.; Gingeras, T. R.; Schoolnik, G.; Akira, S.; Takeda, K.; Ehrt, S. MyD88 primes macrophages for full-scale activation by interferon-gamma yet mediates few responses to Mycobacterium tuberculosis. J. Exp. Med. 2003, 198, 987-997.

(61) Shi, S.; Ehrt, S. Dihydrolipoamide acyltransferase is critical for Mycobacterium tuberculosis pathogenesis. Infect. Immun. 2006, 74, 5663.

(62) Ehrt, S.; Schnappinger, D.; Bekiranov, S.; Drenkow, J.; Shi, S.; Gingeras, T. R.; Gaasterland, T.; Schoolnik, G.; Nathan, C. Reprogramming of the macrophage transcriptome in response to interferon-gamma and Mycobacterium tuberculosis: signaling roles of nitric oxide synthase-2 and phagocyte oxidase. J. Exp. Med. 2001, 194, $1123-1140$. 